(2) norden 



\section{Ekonomiska utsikter i Norden 2008}

Nordiska konjunkturgruppens redogörelse hösten 2007 
Ekonomiska utsikter i Norden 2008

Nordiska konjunkturgruppens redogörelse hösten 2007

TemaNord 2007:588

(C) Nordiska ministerrådet, Köpenhamn 2007

ISBN 978-92-893-1585-2

Tryck: Ekspressen Tryk \& Kopicenter. Only available as print-on-demand

Tryckt på miljövänligt papper som uppfyller kraven i den nordiska miljösvanemärkningen.

Publikationen kan beställas på www.norden.org/order. Fler publikationer på

www.norden.org/publikationer

Printed in Denmark

Nordiska ministerrådet

Store Strandstræde 18

DK-1255 Köpenhamn K

Telefon $(+45) 33960200$

Fax (+45) 33960202

www.norden.org

\section{Nordiska rådet}

Store Strandstræde 18

DK-1255 Köpenhamn K

Telefon (+45) 33960400

Fax (+45) 33111870

\section{Det nordiska samarbetet}

Det nordiska samarbetet är ett av världens mest omfattande regionala samarbeten. Det omfattar Danmark, Finland, Island, Norge och Sverige samt de självstyrande områdena Färöarna, Grönland och Åland.

Det nordiska samarbetet är politiskt, ekonomiskt och kulturellt förankrat och är en viktig partner i europeiskt och internationellt samarbete. Den nordiska gemenskapen arbetar för ett starkt Norden i ett starkt Europa.

Det nordiska samarbetet vill styrka nordiska och regionala intressen och värderingar i en global omvärld. Gemensamma värderingar länderna emellan bidrar till att stärka Nordens ställning som en av världens mest innovativa och konkurrenskraftiga regioner. 


\section{Innehåll}

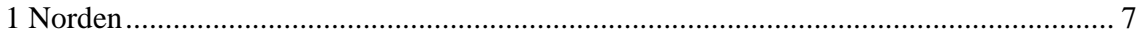

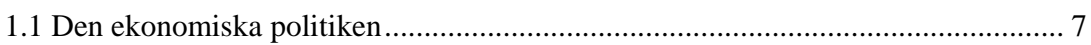

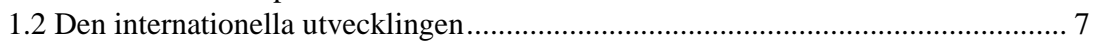

1.3 Den ekonomiska utvecklingen i Norden............................................................... 9

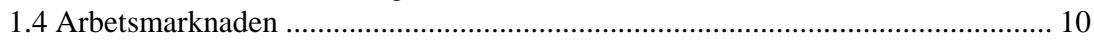

1.5 Penningpolitiken och pris- och kostnadsutvecklingen......................................... 11

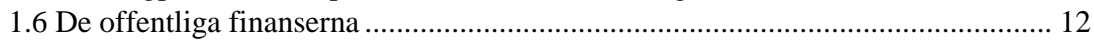

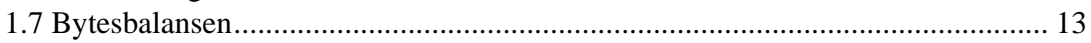

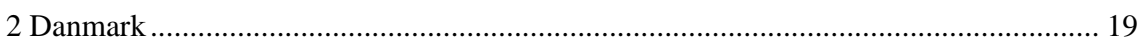

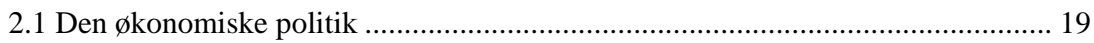

2.2 Udviklingen i dansk økonomi ............................................................................ 21

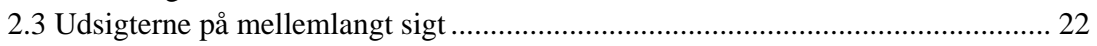

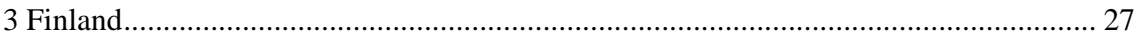

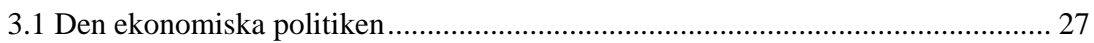

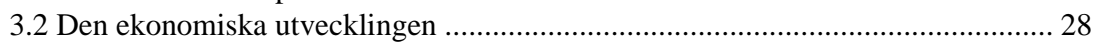

3.3 Utsikterna på medellång sikt .............................................................................. 29

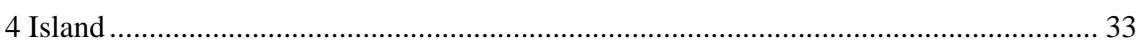

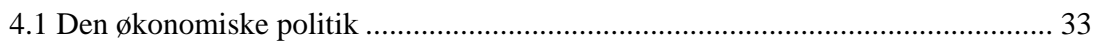

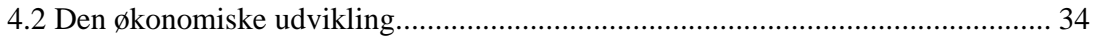

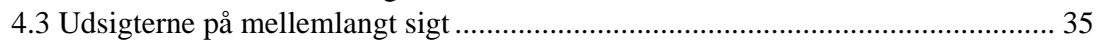

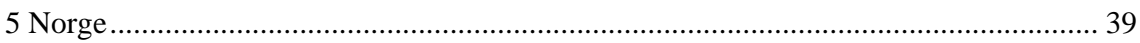

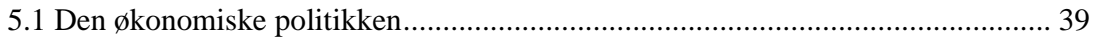

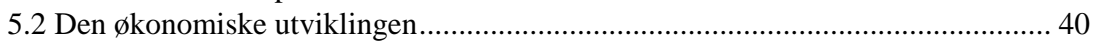

5.3 Utsiktene på mellomlang sikt ............................................................................. 41

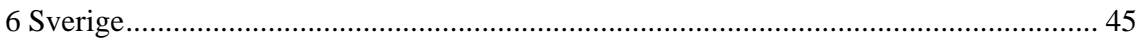

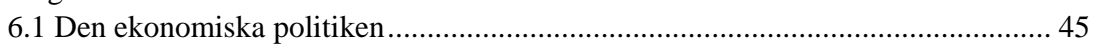

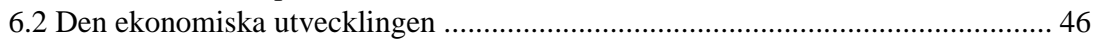

6.3 Utsikterna på medellång sikt ........................................................................... 46 



\section{Norden}

\subsection{Den ekonomiska politiken}

Gemensamma mål för den ekonomiska politiken i de nordiska länderna är hög och hållbar ekonomisk tillväxt, hög sysselsättning och prisstabilitet. En grundläggande förutsättning för att uppnå dessa mål är en väl avvägd makroekonomisk politik baserad på sunda offentliga finanser.

Den demografiska utvecklingen, med en påtagligt ökande andel äldre i befolkningen under det närmaste halvseklet, ställer ökade krav på sunda offentliga finanser i dagsläget. För att kunna bibehålla en väl utvecklad ekonomisk välfärd i framtiden krävs ett högt sparande i den offentliga sektorn under de kommande åren och ansträngningar för att öka antalet personer i arbete.

\subsection{Den internationella utvecklingen}

Världsekonomins ovanligt starka uppgångsperiod fortsätter för fjärde året i rad. Från fjolårets 5,4 \% kommer tillväxten att mattas av till cirka 5 \% i år och fortsätter på 41/2-procentstakten 2008. Globaliseringen har minskat på industriprodukternas priser, vilket kompenserat för råvaruprisernas prisstegring på grund av efterfrågan, vilket i sin tur har förstärkt den positiva spiralen för världsekonomin. Den starka globala expansionen i år beror framför allt på den mycket höga tillväxten i Kina, Indien och en del andra tillväxtekonomier, men även Europa och Japan bidrar till den starka konjunkturen. BNP-tillväxten i USA på $2 \%$ är dock lägre än den trendmässiga tillväxten. Den främsta anledningen till den dämpade tillväxten i USA är en nedsatt efterfråga och fallande bostadsinvesteringar. Under de kommande två åren dämpas den globala tillväxten något, främst till följd av en cyklisk avmattning i företagens investeringar och den senaste tidens turbulens på den finansiella marknaden. De realekonomiska effekterna av den pågående finansiella krisen är svårbedömda. Risken för en svagare internationell utveckling har dock ökat.

Den starka globala tillväxten har lett till att resursutnyttjandet blivit allt mer ansträngt så att produktivitetstillväxten avtar och kostnadstrycket växer. Oljepriset har också stigit under året 2007. Under de närmaste åren väntas dock oljepriset falla tillbaka, men det växande inflationstrycket fortsätter till följd av att lönerna ökar snabbare än tidigare i stora delar av världsekonomin. Det högre inflationstrycket innebär att centralbankerna i Europa pressas att fortsätta en åtstramande penningpolitik, vilket har bidra till att den finansiella krisen. Däremot har den amerikanska central- 
banken (Fed) nyligen indikerat att hoten mot en sund utveckling har ökat markant till följd av osäkerheten på finansmarknaderna. Därför förväntas Fed sänka sin styrränta ytterligare från nuvarande 4,75 \%.

Förenta staternas ekonomi växte med 2,9 \% i fjol och den beräknas öka i år med knappa $2 \%$. Det är uppenbart att den amerikanska ekonomin är inne i en betydlig lugnare tillväxtfas än tidigare. Produktionsökningen var lam under första hälften av 2007, och återspeglade den markanta minskningen av bostadsbyggandet. Situationen på bostadsmarknaden har försämrats i största allmänhet: försäljningstiden för nya bostäder har förlängts och antalet osålda gamla bostäder är det största på nästan ett par årtionden. Under första hälften av 2007 har arbetslösheten varit oförändrad, men den kommer att öka i år och nästa år till följd av den avtagande ekonomiska tillväxten. Landets externa balans i förhållande till totalproduktionen har långsamt börjat förbättras. Totalproduktionen bedöms öka nästa år med 21/2\% och den här uppväxlingen beror främst på att bostadsinvesteringarna då stabiliseras.

Euroområdets ekonomiska utveckling tog äntligen fart i fjol då tillväxten i investeringarna ökade och den offentliga konsumtionen, exporten och den inhemska efterfrågan tilltog. År 2006 ökade BNP med 2,7 \%, den högsta farten sedan 2000, och tillväxten förväntas fortsätta med nästan samma hastighet under innevarande år men mattas av igen nästa år. Under de två senare åren har Tyskland agerat tillväxtlok, men förväntningarna har redan börjat avta även om sysselsättningen fortsättningsvis utvecklats gynnsamt. En svagare global efterfrågan i kombinationen med en starkare euro väntas leda till att exporttillväxten dämpas de närmaste åren.

En tilltagande produktivitetstillväxt och återhållsam löneökningstakt har bidragit till en god vinstutveckling hos företagen. Utsikterna för arbetsmarknaden och de offentliga finanserna har ljusnat: arbetslösheten i euroområdet som helhet har sjunkit och budgetbalanserna har förbättrats. Lönehöjningarna i euroområdet är något större än tidigare, vilket vid sidan av förbättrad sysselsättning ökar inkomsterna och påskyndar ökningen av den privata konsumtionen. Kapacitetsutnyttjandet ligger på hög nivå men investeringsuppgången väntas kulminera i år. Hushållens och företagens förtroende ligger ännu på en hög nivå, men det har avtagit under hösten. Produktionen i euroområdet beräknas öka med 21/2\% i år och med knappa 21/2\% nästa år.

Asien är åter den region som haft den snabbaste tillväxten i fjol, och förutsättningarna är goda för en fortsatt hög tillväxt även under de närmaste åren. Den inhemska efterfrågan och handeln inom Asien blir en allt viktigaste drivkraft för hela regionen. Kinas starka ekonomiska tillväxt har tilltagit ytterligare. År 2006 ökade BNP med 11,1 \% och det bedöms öka nästan i samma takt både i år och nästa år. Både konsumtionen och investeringarna har ökat kraftigt, och det har medfört en hög kredittillväxt. Dessutom har konsumentpriserna börjat stiga allt snabbare. Oron för 
en alltför snabb ekonomisk tillväxt har ökat, och centralbanken har redan höjt räntan tre gånger i år, ökat på bankernas reservskyldighet och emitterat nya skuldebrev. Japans ekonomi har fortsatt på den starka tillväxtfas som inleddes i slutet av 2006. Företagens goda lönsamhet har ökat investeringarna, som uppmuntras av de goda exportutsikterna till följd av den försvagade yenen. BNP bedöms öka med $2 \%$ både i år och nästa år.

\subsection{Den ekonomiska utvecklingen i Norden}

Generellt sett befinner sig de nordiska ekonomierna i ett gynnsamt läge jämfört med euroområdet. BNP-tillväxten i Norden var nästan rekordstark i fjol, dryg $4 \%$, understödd generellt av en stark investeringsutveckling och privat konsumtion, samt av nettoexport i Finland och i Sverige. I Finland växte BNP över $5 \%$, i Sverige, Fastlands-Norge och Island över $4 \%$ och i Danmark 31/2\%. Med hänsyn till deras generellt låga arbetslöshet har trycket mot produktionskapaciteten ökat $\mathrm{i}$ alla de nordiska ekonomierna. Den ekonomiska tillväxten i Norden börjar avta, men takten är trots det fortfarande tämligen kraftig och kommer att överstiga euroområdets tillväxt även nästa år.

Under 2007 har den danska ekonomiska tillväxten gått in i en mognare fas. BNP-tillväxten i Danmark förväntas bli 2 \% i år och 1,3 \% nästa år. Den svagare tillväxten beror framför allt på stigande räntor, långsammare inkomstutvecklingen för hushållen och på fallande bostadsinvesteringar. Den svaga inhemska efterfrågan kompenserar åtstramningarna i det inhemska utbudet, till följd av det stigande resursutnyttjandet som beror på den sjunkande arbetslösheten. Exporttillväxten förväntas avta under de kommande åren på grund av det höga resursutnyttjandet.

Den finländska ekonomin är fortsättningsvis stark och bedöms öka med 4,4 \% i år och 3,3 \% nästa år. Den ekonomiska tillväxten ligger även nästa år alldeles intill gränserna för produktionsmöjligheterna. På samma sätt som 2006 stöder både nettoexporten och den inhemska efterfrågan tillväxten men tyngdpunkten förskjuts ändå till den inhemska efterfrågan. Ökningen av köpkraften och sysselsättningen stöder fortfarande konsumtionsefterfrågan. Hushållens ökande skuldsättning utgör dock i kombination med det tilltagande pris- och kostnadstrycket inhemska riskfaktorer.

Efter en mycket stark tillväxtperiod var BNP-tillväxten i Island ännu 4,2 \% i fjol. Takten har blivit märkbart lugnare i år efter att de stora (aluminum-relaterade) investeringsprojekten har blivit nästan färdiga. Den privata konsumtionen dämpas också, och BNP-tillväxten bedöms sakta ner till 0,7 \% i år. Islands BNP förväntas växa i genomsnitt med 11/2\% de två kommande åren. Exportillväxten är fortsättningsvis kraftig på grund av den utökade aluminiumproduktionskapaciteten. Exportillväxten förbättrar dessutom underskottet $\mathrm{i}$ handelsbalansen när importen samtidigt minskar. 
BNP-tillväxten i den norska ekonomin är fortfarande mycket stark främst till följd av ökande investeringar och en mycket god utveckling av den privata konsumtionen. Den kraftiga ökningen av produktionskapaciteten har inte minskat trycket i ekonomin eftersom även exporten och den offentliga konsumtionen fortsätter att öka snabbt. Den kraftiga ekonomiska tillväxten beräknas dock plana ut något under de kommande åren. BNP i Fastlands-Norge förväntas växa med 5,0 \% i år och 2,8 \% nästa år. Hushållens konsumtionstillväxt och investeringsökningarna försvagas på grund av åtstramningar i penningpolitiken under det kommande året.

Den svenska ekonomin växer fortfarande i god takt. Förra årets BNPtillväxt på 4,2 \% var resultatet av både kraftig inhemsk och utländsk efterfrågan. Under 2007 och 2008 förändras efterfrågans sammansättning till följd av inbromsningen i investeringar och export och en stark ökning i hushållens konsumtion. Både i år och nästa år förväntas BNP-tillväxten bli 3,2 \%. Hushållens konsumtion ökar snabbt till följd av stigande reallöner, ökande sysselsättning, betydande skattesänkningar samt en sjunkande sparkvot. Det höga resursutnyttjandet bedöms bidra till en dämpning av tillväxten de två kommande åren, bl.a. till följd av stigande räntor och arbetskraftkostnader.

\subsection{Arbetsmarknaden}

Sysselsättningen i Norden ökade i rask takt i fjol, vilket är typisk för högkonjunkturer, med dryga 2 procent; i Island och Norge till och med så mycket som 5,1 respektive 3,1 \%. I en del av de Nordiska länderna har den ökade arbetsinvändningen från de nya EU-länderna bidragit till sysselsättningsökningen på ett betydande sätt. Arbetslösheten sjönk också, men är fortsättningsvis hög i Finland. Arbetslösheten sjunker ytterligare i år och nästa år. Arbetsmarknaden förblir stram särskilt i Norge, Danmark och Island, men även i Finland, där arbetslösheten förblir jämförelsevis hög, blir det ett allt svårare problem att de lediga platserna och arbetssökandena inte matchar. Även i Sverige börjar tecken på arbetskraftsbrist synas.

Sysselsättningen i Danmark har utvecklats positivt under se senaste åren främst inom den privata sektorn. Sysselsättningen beräknas öka snabbt även i år, med 1,7 \%, men minska redan lite nästa år. Arbetslösheten fortsätter att minska och har nått den lägsta nivån på tre årtionden. Nästa år förväntas arbetslöshetsgraden sjunka till 3,1 \%.

I Finland har situationen på arbetsmarknaden också förbättrats den senaste tiden. Sysselsättningsgraden beräknas stiga från fjolårets 68,9 \% till 70 \% i år och 70,5 \% nästa år. Tillväxten riktar sig i första hand till service- och byggbranscherna, men i någon mån också till industrin. Arbetslösheten sjunker från fjolårets $7,7 \%$ till 6,7 \% i år, och beräknas sjunka vidare till 6,3 \% nästa år. 
Islands arbetsmarknad förblir stram. Fjolårets sysselsättningsökning på dryga 5 procent kommer att avta kraftigt $\mathrm{i}$ år och minska även nästa år. Arbetslöshetsgraden beräknas sjunka från fjolårets 1,3 \% till 1,1 \% i år. Nästa år väntas nedgången av den inhemska efterfrågan höja arbetslösheten till ett genomsnitt på 2,9 \%.

Den höga aktiviteten i den norska ekonomin har lett till en ökning i sysselsättningen och en nedgång i arbetslöshetsgraden. Sysselsättningen väntas öka med 2,5 \% i år, och arbetslösheten beräknas sjunka från 3,4 \% till 2,5 \%. Sysselsättningsökningen beräknas bli långsammare under den närmaste tiden, men arbetslösheten förväntas hålla sig på en låg nivå.

Den starka ekonomiska tillväxten garanterar en positiv utveckling på den svenska arbetsmarknaden, och sysselsättningen väntas öka med 2,3 \% i år och 1,2 \% nästa år. Arbetskraften förväntas också öka, och den öppna arbetslösheten sjunker från fjolårets 5,4 \% till 4,4 \% i år och 4,0 \% nästa år. Arbetslösheten är dock $1 \frac{112}{2}$ procentenheter högre enligt ILOdefinitionen. Förändringar i arbetsmarknadspolitiken och genomförda reformer kommer bidra till att öka sysselsättningen och arbetskraften de kommande åren.

\subsection{Penningpolitiken och pris- och kostnadsutvecklingen}

Penningpolitiken i Norden styrs av ländernas egna centralbanker, utom i Finland där den styrs av Europeiska centralbanken (ECB). Det övergripande penningpolitiska målet i de nordiska länderna är prisstabilitet.

Finlands medlemskap i EMU innebär att penningpolitiken styrs av ECB. Den primära målsättningen för ECB är att fastställa en styrränta som bibehåller prisstabilitet. Prisstabilitetsmålet är att hålla inflationen på nivåer strax under $2 \%$. Danmarks penningpolitik är inriktad på att kronan ska följa euron inom ett fluktuationsband på +/- 2,25 procentenheter. I praktiken är fluktuationsbandet mindre. Islands penningpolitik kännetecknas sedan 2001 av en självständig centralbank vars mål är prisstabilitet. Den isländska centralbankens målsättning är att inflationen ska vara omkring 2,5\% med ett toleransintervall på +/- 1,5 procentenheter. Det operativa målet för den norska penningpolitiken är att hålla inflationen omkring 2,5\% över tid. Den svenska penningpolitiken styrs av Riksbanken som också har ett prisstabilitetsmål. Riksbankens mål är att hålla inflationen omkring $2 \%$ med ett toleransintervall på +/- 1 procentenhet.

Inflationen har generellt sett varit låg i Norden, knappa $2 \%$, med undantag av Island, där takten dock förväntas sakta. Antydningar om prisökningar har dock kommit till synes på grund av den starka efterfrågan och BNP-tillväxten. Den goda vinstutvecklingen och strama arbetsmarknaden höjer dessutom lönetrycket. Den stigande inflationen innebär att inflationen i Norden förväntas bli högre än i Euroområdet under 2008. 
Den danska underliggande inflationen väntas vara fortsatt relativt låg $\mathrm{i}$ år för att stiga i takt med att löneökningarna tilltar under 2008. Inflationen bedöms öka i år till 1,8 \% och till 2,5 \% nästa år. Lönekostnaderna bedöms växa i genomsnitt med drygt 4,5 \% i år och nästa år.

I Finland har arbetskostnaderna ökat måttfullt de senaste åren, vilket har bidragit till att hålla inflationen nere. Inflationen tilltog emellertid under 2007 till följd av stigande boendekostnader och konsumentpriserna har i år stigit nästan en procentenhet snabbare än året innan och takten närmar sig 2,5 \%. År 2008 stiger lönerna klart snabbare i och med de nya inkomstavtalen och prisnivån höjs också av förhöjningarna av de indirekta skatterna samt hälso- och sjukvårdavgifterna. Boendekostnaderna stiger å andra sidan igen långsammare, så att den genomsnittliga inflationen förblir så gott som oförändrad 2008.

I Island har inflationstrycket minskat till följd av kronans stabilisering och inflationen väntas sakta in i år till 4,5 \% från 6,8 \% senaste år. Inflationstrycket är dock alltjämt mycket starkt och Islands centralbank beslöt i maj 2007 att hålla styrräntenivån på 14,25 \%. Konsumentprisindexet förväntas stiga 3,3 \% nästa år.

Den norska inflationen har minskat jämfört med fjolåret till följd av nedgången i elpriserna. Den underliggande inflationen, mått med konsumentprisindexet justerat enligt avgiftsändringar exklusive energiprodukter, ligger i genomsnitt på 1,5 \% i år. Norges Bank har ökat takten vid normaliseringen av styrräntan, och i slutet av 2007 bedöms styrräntan öka något från nuvarande 5,0 \% nivån. Den tillfälligt låga inflationen $\mathrm{i}$ år kommer att efterföljas av en tillfälligt högre inflation nästa år, då konsumentpriserna bedöms stiga med 2,5 \%.

Inflationen kommer att öka i Sverige på grund av en kombination med växande resursutnyttjande, en långsammare produktivitetsutveckling och tilltagande löneökningar. Jämfört med fjolårets 1,4 \% stiger konsumentpriserna i år i genomsnitt med 2,2 \% och 2,8 \% nästa år. Den underliggande inflationstakten förblir lite långsammare, men kommer att hamna intill Sveriges riksbanks mål på 2 \%. Styrräntan har höjts från fjolårets 1,5 \% till 3,75 \% i år, och ytterligare åtstramningar väntas framöver.

\subsection{De offentliga finanserna}

De nordiska länderna klarar sig väl i jämförelse med de mesta euroländerna med avseende balanserna i den offentliga ekonomin. Till skillnad från många euroländer uppvisar länderna i Norden stora överskott i sina offentliga finanser och denna utveckling beräknas hålla i sig även under nästa år.

Sunda offentliga finanser är en förutsättning för en hållbar ekonomisk tillväxt och en hållbart hög sysselsättning. För att understryka vikten av detta har länderna i Norden satt upp likartade budgetpolitiska mål för de 
offentliga finanserna. I Danmark är det uppställda målintervallet för det strukturella offentliga överskottet 0,75-1,75 \% av BNP i genomsnitt fram till 2010. Finland har som mål att upprätthålla sunda offentliga finanser och att statens strukturella överskott motsvarar en procent av bruttonationalprodukten i slutet av valperioden 2011. Ökningen av de offentliga utgifterna dämpas genom en utgiftsram för utgiftsökningarna som sträcker sig till och med över valperioden. I Island är det budgetpolitiska målet att inte öka den offentliga konsumtionen i reella termer med mer än $2 \%$ per år och att begränsa transfereringstillväxten till 2,5 \% per år. I Sverige styrs finanspolitiken av två medelfristiga mål. Målet för överskottet innebär att den offentliga sektorns genomsnittliga finansiella sparande ska uppgå till $1 \%$ av BNP över en konjunkturcykel. För den andra ska statens och ålderpensionssystemets sammantagna utgifter rymmas inom ett utgiftstak som beslutas i förväg. Däröver finns det för den kommunala sektorn det s.k. balanskravet. I Norge ska budgetpolitiken följa den så kallade handlingsregeln som säger att det oljekorrigerade strukturella budgetunderskottet över tiden ska vara lika med och finansieras med den förväntade reella avkastningen på Statens pensionsfond - Utland.

Danmarks offentliga överskott beräknas vara mellan 3-4 \% av BNP i år och nästa år. En del av detta överskott är tillfälligt och det strukturella överskottet beräknar vara ca $1,5 \%$ av BNP nästa år. Finlands överskott stiger till 4,5 \% av BNP i år, varifrån det nästa år sjunker med en halv procentenhet. Både skatterna och utgifterna sjunker i förhållande till bruttonationalprodukten i år men nästa år sjunker bara skattesatsen något. I Island minskar överskottet i år till 3,9 \% från 5,3 \% i fjol. Islands överskott beräknas minska ytterligare till $0,7 \%$ av BNP nästa år. Sveriges överskott år 2006 uppgick till 2,4 \% av BNP, det största överskott som redovisats sedan 2000. I Sverige förväntas överskottet uppgå till 2,9 \% av BNP i år och 2,8 \% av BNP nästa år. Norges intäkter från oljeutvinningen gör att landet har ett betydligt högre överskott i de offentliga finanserna än de övriga länderna i Norden. Överskott i de offentliga finanserna beräknas uppgå till 17,3 \% av BNP i år och 15,0 \% nästa år. Det oljekorrigerade strukturella underskottet beräknas uppgå till 3,7 \% av BNP i år jämfört med fjolårets $4 \%$ av BNP.

\subsection{Bytesbalansen}

De nordiska länderna klarar sig väl i jämförelse med de mesta euroländerna med hänsyn till balansen i utrikeshandeln. Bytesbalansen har visat överskott i de flesta nordiska länderna de senaste åren, och denna utveckling beräknas hålla i sig även framöver. Norge har tack vare sina oljeinkomster en särställning, Finland och Sverige har också stora överskott i bytesbalansen, men Danmark har ett relativt litet överskott. $\AA$ andra sidan har Island dock ett stort underskott i bytesbalansen. 
Finlands bytesbalansöverskott bedöms uppgå till 4,8 \% av BNP i år och 4,6 \% av BNP nästa år. Som motvikt till hushållssektorns underskott är den offentliga ekonomins och företagens inkomster märkbart större än utgifterna i förhållande till BNP. Norges bytesbalansöverskott, som i stor utsträckning påverkas av oljepriset, beräknas bli 13,0 \% av BNP i år. Innevarande års överskott är 3,5 procentenheter lägre än i fjol och bedöms uppgå till 11,4 \% nästa år. Sveriges bytesbalansöverskott bedöms uppgå till 7,3 \% av BNP i år, främst tack vare det stora överskottet i utrikeshandeln. De kommande åren beräknas handelsnettot bidra mindre till bytesbalansens utveckling samtidigt som tjänstenettot förstärks ytterligare. Nästa år beräknas Sveriges överskott öka ytterligare och uppgå till $7,4 \%$ av BNP.

Danmarks bytesbalansöverskott är relativt litet jämfört med de ovan nämnda länderna. Danmarks överskott har minskat i år jämför med i fjol från 2,4 \% av BNP till 1,7 \% av BNP, och beräknas minska ytterligare till $1,2 \%$ av BNP nästa år. Island är det enda land som har ett bytesbalansunderskott. Underskottet i den isländska bytesbalansen beräknas bli 15,2 \% av BNP i år och bedöms minska till 8,8 \% av BNP nästa år, till följd av investeringsprojektens positiva inverkan på bytesbalansen. 
Tabell 1.1 Nyckeltal, Norden

\begin{tabular}{|c|c|c|c|c|c|}
\hline & 2004 & 2005 & 2006 & 2007 & 2008 \\
\hline \multicolumn{6}{|l|}{ BNP-tillväxt, \% } \\
\hline Danmark & 2,1 & 3,1 & 3,5 & 2,0 & 1,3 \\
\hline Finland & 3,7 & 2,9 & 5,0 & 4,4 & 3,3 \\
\hline Island & 7,7 & 7,1 & 4,2 & 0,7 & 1,2 \\
\hline Norge & 3,9 & 2,7 & 2,8 & 3,5 & 3,1 \\
\hline Sverige & 4,1 & 2,9 & 4,2 & 3,2 & 3,2 \\
\hline Norden, vägt genomsnitt & 3,6 & 2,9 & 3,9 & 3,2 & 2,7 \\
\hline \multicolumn{6}{|l|}{ Inflation, \% (KPI) } \\
\hline Danmark & 1,2 & 1,8 & 1,9 & 1,8 & 2,5 \\
\hline Finland & 0,2 & 0,9 & 1,6 & 2,4 & 2,4 \\
\hline Island & 3,2 & 4,0 & 6,8 & 4,5 & 3,3 \\
\hline Norge & 0,5 & 1,5 & 2,3 & 0,6 & 2,6 \\
\hline Sverige & 0,4 & 0,5 & 1,4 & 2,2 & 2,8 \\
\hline Norden, vägt genomsnitt & 0,6 & 1,1 & 1,8 & 1,8 & 2,6 \\
\hline \multicolumn{6}{|l|}{ Arbetslöshet, \% } \\
\hline Danmark & 6,1 & 5,5 & 4,3 & 3,3 & 3,1 \\
\hline Finland & 8,8 & 8,4 & 7,7 & 6,7 & 6,3 \\
\hline Island & 3,1 & 2,1 & 1,3 & 1,1 & 2,9 \\
\hline Norge & 4,5 & 4,6 & 3,4 & 2,5 & 2,5 \\
\hline Sverige & 7,7 & 7,7 & 7,1 & 6,0 & 5,5 \\
\hline Norden, vägt genomsnitt & 6,8 & 6,6 & 5,7 & 4,7 & 4,4 \\
\hline \multicolumn{6}{|c|}{ Offentlig finansiellt sparande, $\%$ av BNP } \\
\hline Danmark & 1,9 & 4,6 & 4,7 & 3,9 & 3,1 \\
\hline Finland & 2,1 & 2,5 & 3,7 & 4,4 & 3,8 \\
\hline Island & 0,2 & 5,2 & 7,0 & 4,7 & 0,6 \\
\hline Norge & 11,1 & 15,2 & 18,1 & 17,3 & 15,0 \\
\hline Sverige & 0,6 & 2,0 & 2,4 & 2,9 & 2,8 \\
\hline Norden, vägt genomsnitt & 3,7 & 5,3 & 6,0 & 5,9 & 5,2 \\
\hline \multicolumn{6}{|l|}{ Bytesbalans, $\%$ av BNP } \\
\hline Danmark & 3,1 & 3,8 & 2,4 & 1,7 & 1,3 \\
\hline Finland & 7,6 & 4,9 & 4,7 & 4,8 & 4,6 \\
\hline Island & $-9,9$ & $-16,1$ & $-25,7$ & $-15,2$ & $-8,8$ \\
\hline Norge & 12,7 & 15,5 & 16,4 & 13,0 & 11,4 \\
\hline Sverige & 6,9 & 7,0 & 7,2 & 7,3 & 7,4 \\
\hline Norden, vägt genomsnitt & 7,1 & 7,3 & 7,1 & 6,4 & 6,0 \\
\hline
\end{tabular}

Källor: Nationella källor 


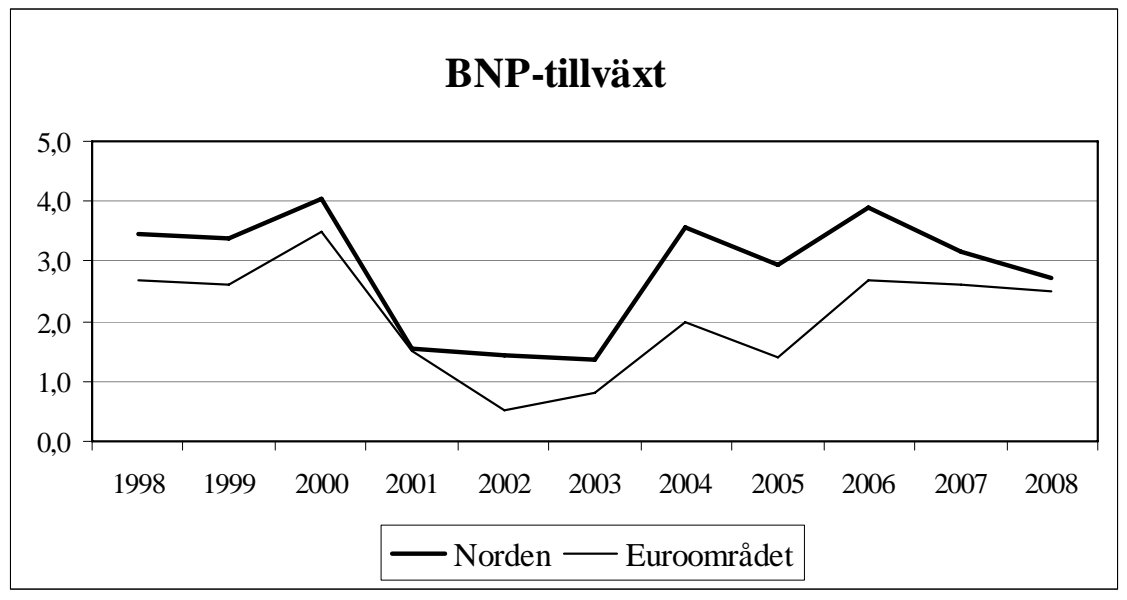

Figur 1.1 BNP-tillväxt. Årlig procentuell förändring, vägt genomsnitt.

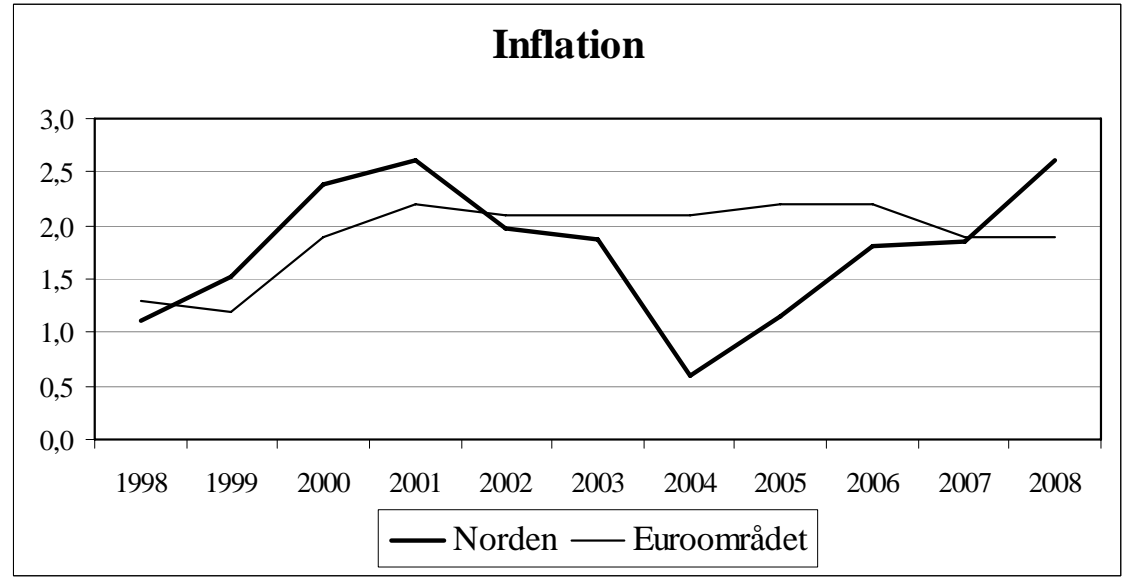

Figur 1.2 Inflation. Procent, vägt genomsnitt.

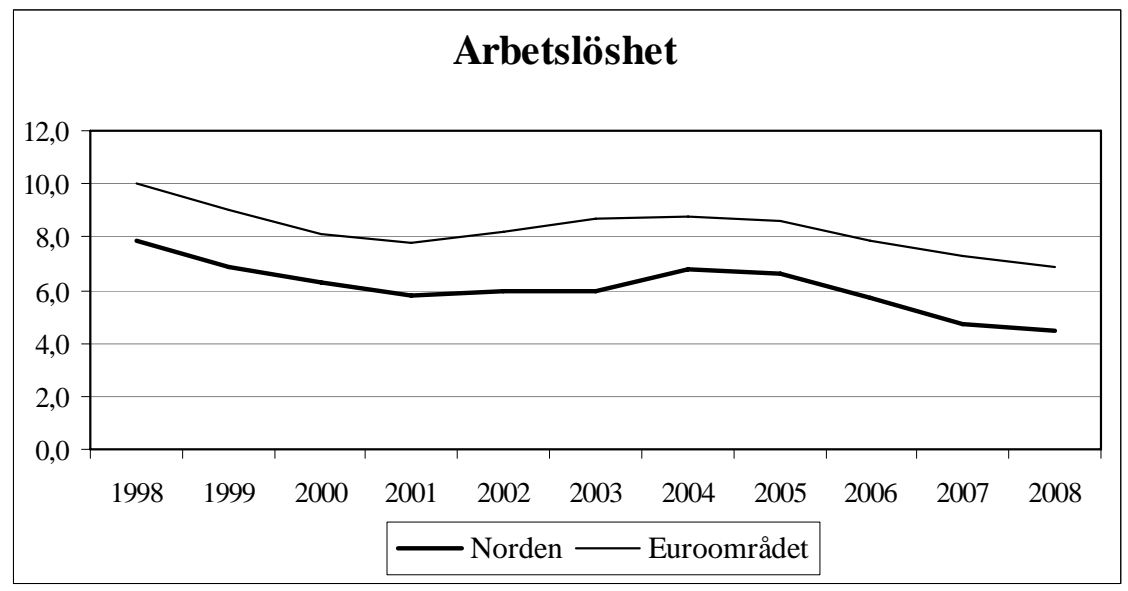

Figur 1.3 Arbetslöshet. Procent, vägt genomsnitt. 


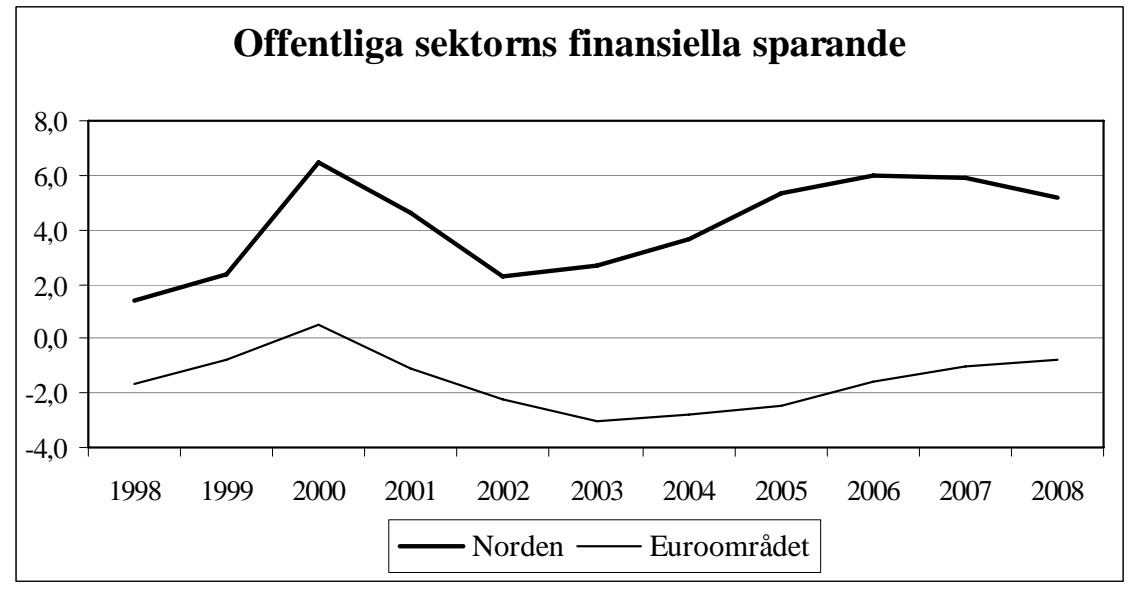

Figur 1.4 Offentliga sektorns finansiella sparande. Procent av BNP, vägt genomsnitt.

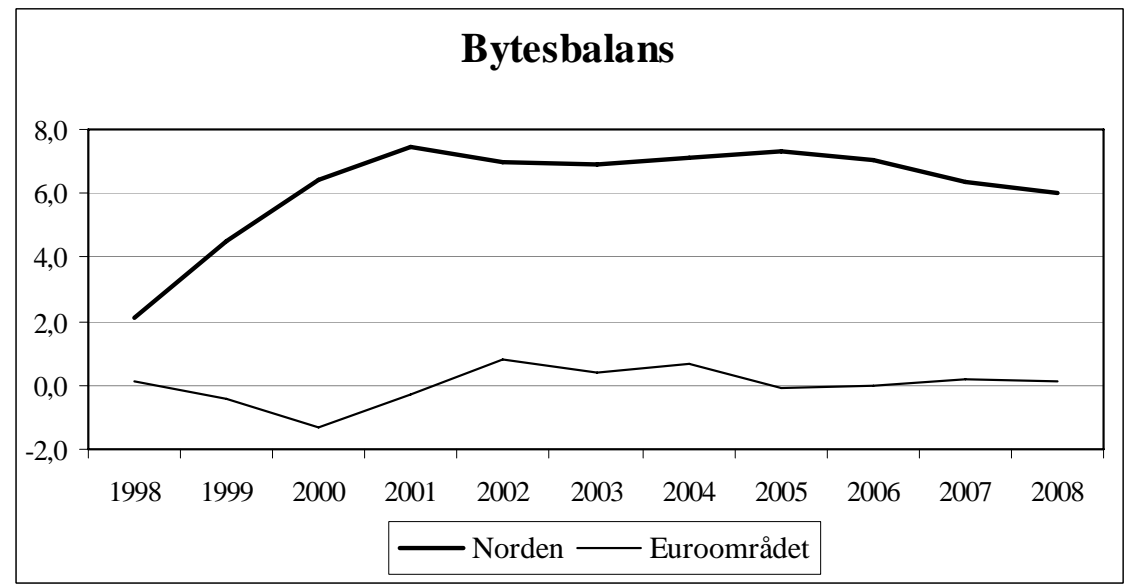

Figur 1.5 Bytesbalans. Procent av BNP, vägt genomsnitt.

Källor: Nationella källor och Eurostat. 



\section{Danmark}

\subsection{Den økonomiske politik}

Det er et mål for den økonomiske politik at sikre holdbar økonomisk vækst, høj beskæftigelse og lav og stabil inflation. Med henblik på at opnå disse mål er der i tilrettelæggelsen af den økonomiske politik et særligt fokus på at sikre tilstrækkelig arbejdskraft til både den private og offentlige sektor. Herunder ikke mindst med henblik på at håndtere udfordringerne fra den demografiske udvikling, hvor der bliver flere ældre og færre i de mest erhvervsaktive aldersgrupper. En anden udfordring er at ruste det danske samfund til globaliseringen og sikre, at alle grupper i samfundet deltager og får del i den fremgang som følge af globaliseringen.

I august 2007 fremlagde regeringen en ny flerårig økonomisk plan Mod nye mål - Danmark 2015. Sigtepunktet er fortsat finanspolitisk holdbarhed, således at velfærdssamfundet også skal kunne finansieres på langt sigt, uden at der fremkommer et behov for større fremtidige finanspolitiske stramninger.

I 2015-planen er det målsætningen, at der frem mod 2010 fastholdes strukturelle offentlige overskud (renset for konjunkturer og andre midlertidige forhold) mellem 3/4 og 13/4 \% af BNP. Fra 2011 til 2015 skal der være mindst balance.

I 2007 skønnes det strukturelle offentlige overskud at ligge i den øvre ende af målintervallet. Hertil kommer et væsentligt bidrag fra den nuværende højkonjunktur, således at det faktiske offentlige overskud ventes at blive 3,9\% af BNP i 2007.

Frem mod 2015 er det et krav, at nye initiativer skal øge den strukturelle beskæftigelse med 20.000 personer og sikre at den gennemsnitlige arbejdstid ikke falder. For at opfylde 2015-planens krav om øget beskæftigelse og uændret arbejdstid nedsættes en arbejdsmarkedskommission med uafhængige eksperter. Inden udgangen af 2008 skal kommissionen præsentere sine anbefalinger med henblik på at øge beskæftigelse og arbejdstid.

For at styrke beskæftigelsen har regeringen derudover annonceret en 10-punkts jobplan med konkrete initiativer til at skaffe mere arbejdskraft i Danmark - dels ved at give overførselsmodtagere bedre mulighed for at komme i arbejde og dels ved at tiltrække kvalificeret arbejdskraft fra 
udlandet. 10-punktsplanen skal navnlig ses i sammenhæng med den nuværende rekordlave ledighed og store efterspørgsel efter arbejdskraft i både den private og den offentlige sektor.

Strategien for holdbare offentlige finanser forudsætter derudover blandt andet, at aldersgrænserne for efterløn og pension i overensstemmelse med Velfærdsaftalen løftes fra 2019 og derefter i takt med levetiden. Det sikrer, at de offentlige finanser bliver mere robuste over for stigende levetid.

Skattepolitikkens omdrejningspunkt er fortsat skattestoppet, der indebærer, at en skat eller afgift ikke må stige, uanset om den er fastsat i procent eller nominelle kronebeløb. Som led i energi- og klimastrategien indekseres energiafgifterne. I overensstemmelse med skattestoppet medgår merprovenuet fra energiafgifterne til nedsættelse af skatten på arbejde.

For at understøtte vækst og fremgang i arbejdsudbuddet nedsættes skatten på arbejdsindkomst fra og med 2008. Samlet nedsættes indkomstskatten med 91/2 mia. kr. For at styrke gevinsten ved at arbejde øges beskæftigelsesfradraget og i 2009 løftes mellemskattegrænsen. Skattenedsættelsen er finansieret inden for rammerne af skattestoppet ved at afskaffe arbejdsmarkedsfonden og ved som nævnt at fastholde energiafgifternes realværdi. Skattenedsættelsen skønnes at løfte arbejdsudbuddet svarende til 8.000 fuldtidspersoner, navnlig via et forventet positivt bidrag til den gennemsnitlige arbejdstid.

Inden for rammerne af 2015-planen er der plads til, at de offentlige forbrugsudgifter kan vokse godt og vel i takt med den samlede økonomi. Kvaliteten i den offentlige service understøttes desuden af regeringens kvalitetsstrategi, som blandt andet skal bidrage til, at den nye kommunale struktur (trådte i kraft 1. januar 2007) også omsættes i bedre offentlig service. I den forbindelse etableres blandt andet en kvalitetsfond på 50 mia. kr., som skal medfinansiere et løft i de offentlige investeringer, herunder ikke mindst byggeri og udstyr inden for sundhedsområdet.

Pengepolitikken fastlægges fortsat med henblik på, at kronekursen skal følge euroen inden for et snævert udsvingsbånd. Det sikrer, at inflationen følger den mellemfristede udvikling i euroområdet.

I planlægningen af den økonomiske politik er det et centralt sigtepunkt at sikre økonomisk stabilitet og lav inflation. Det vil sammen med den holdbare linje i finanspolitikken understøtte tilliden til fastkurspolitikken.

Fastkurspolitikken over for euroen betyder, at renteudviklingen i Danmark i praksis er bestemt af renteudviklingen i euroområdet. Den Europæiske Centralbank har hævet styringsrenten flere gange siden starten af 2006. Rentestigningerne betyder, at pengepolitikken i Danmark isoleret set medvirker til at dæmpe væksten i efterspørgslen. 


\subsection{Udviklingen i dansk økonomi}

Dansk økonomi befinder sig omkring toppen af en højkonjunktur med et meget højt niveau for beskæftigelse og økonomisk aktivitet. Ledigheden er faldet til det laveste niveau siden midten af 1970'erne.

Opsvinget er blevet forlænget af en markant stigning i arbejdsudbuddet, som blandt andet afspejler stigende gennemsnitlig arbejdstid, forøget erhvervsdeltagelse blandt de unge og for indvandrere og efterkommere. Desuden har indvandringen af udenlandske arbejdstagere og pendling fra Sverige og Tyskland givet et mærkbart bidrag til arbejdsstyrken.

I Økonomisk Redegørelse, august 2007, har Finansministeriet fremlagt sin seneste prognose for udviklingen i dansk økonomi. I prognosen ventes, at BNP-væksten tager af fra 3,5 \% i 2006 til 2,0 og 1,3 \% i henholdsvis 2007 og 2008.

Den gradvise afdæmpning af den økonomiske vækst skyldes navnlig aftagende vækst i den private, indenlandske efterspørgsel, herunder især boliginvesteringerne. Afdæmpningen af boligmarkedet, efter en periode med kraftig fremgang i både boligpriser og nybyggeri, skal primært ses i lyset af stigende renter, men formentlig også en vis tilbageholdenhed i lyset af tilpasningerne på ejerboligmarkedet.

De seneste økonomisk-statistiske oplysninger, herunder nationalregnskabstal for 2. kvartal 2007, peger på, at væksten i efterspørgslen og produktionen i den første del af 2007 har været lidt lavere end forventet i Økonomisk Redegørelse, august 2007.

Opsvinget har ført til en markant fremgang i beskæftigelsen og en mærkbar mangel på arbejdskraft, herunder ikke mindst i byggeriet. Den registrerede ledighed ventes at ligge på under 100.000 personer i 2007 under ét svarende til 3,3\% af arbejdsstyrken. Den aktuelt lave ledighed giver anledning til pres på arbejdsmarkedet. I de seneste måneder er ledigheden aftaget mere end ventet, og presset på arbejdsmarkedet må derfor vurderes som lidt stærkere.

Det øgede pres på arbejdsmarkedet blev afspejlet i forårets overenskomster for den private sektor, som indebar en væsentlig forøgelse af de aftalte lønstigningerne. Således ventes lønstigningstakten at øges fra 3,6 \% i 2006 til 4,7 \% i 2008. Forventningerne til lønudviklingen indebærer, at de danske virksomheders lønkonkurrenceevne vil blive yderligere forringet.

Trods et betydeligt pres i økonomien er der fortsat overskud på betalingsbalancen - om end der ventes et gradvist fald i overskuddet fra 2,4 $\%$ af BNP i 2006 til 1,2 \% af BNP i 2008. Overskuddene afspejler blandt andet en strukturel forbedring af opsparingen i forhold til tidligere, hvor højkonjunkturer typisk var ensbetydende med betydelige underskud på betalingsbalancen. Samtidig bidrager høje indtægter fra energi og søtransport, som i mindre grad afhænger af de danske konjunkturer, til at overskuddet på betalingsbalancen fortsat er relativt komfortabelt. 
Beskæftigelsen ventes at forblive på et højt niveau i 2008 og presset på arbejdsmarkedet vil fortsat være væsentligt. Initiativerne i velfærdsaftalen fra 2006 forventes i den sammenhæng at reducere ledighedens strukturelle niveau, hvilket vil bidrage til dæmpe presset på arbejdsmarkedet og dermed risikoen for et ustabilt konjunkturforløb.

Samlet set afspejler prognosen i Økonomisk Redegørelse, august 2007, en forventning om en blød landing uden et markant fald i beskæftigelsen.

En usikkerhedsfaktor for dansk økonomi er den meget høje kapacitetsudnyttelse, som præger arbejdsmarkedet. Fortsat kraftig fremgang i efterspørgslen vil kunne medføre større løn- og prisstigninger, der vil forværre konkurrenceevnen og dermed øge risikoen for et ustabilt forløb.

Finanspolitikken ventes på baggrund af regeringens finanslovsforslag at forøge aktiviteten i 2008 - svarende til 0,3 \% af BNP. Mens finanspolitikken således øger den økonomiske aktivitet i 2008, skønnes højere renteniveau at virke dæmpende på væksten i 2007 og 2008. Samlet set er aktivitetsvirkningen fra den økonomiske politik således nogenlunde uændret i forhold til prognosen i maj. Den seneste tids turbulens på de finansielle markeder indebærer dog, at renteudviklingen er forbundet med større usikkerhed end normalt.

\subsection{Udsigterne på mellemlangt sigt}

Finansministeriet har i august offentliggjort en ny mellemfristet fremskrivning frem til 2015. Fremskrivningen er ikke en egentlig prognose, men skal ses som et grundlag for tilrettelæggelsen af finanspolitikken.

Vækstmulighederne i dansk økonomi i årene efter 2007 begrænses af den aktuelt meget lave ledighed, og at den demografiske udvikling isoleret set vil reducere arbejdsstyrken.

I gennemsnit forudsættes en årlig vækst i BNP på knap 11/2\% i perioden 2007-2015. Det er ca. 1/2 \%-enhed mindre end væksten fra 1995 til 2005, hvor væksten blev løftet af stigende beskæftigelse i sammenhæng med en markant reduktion af ledigheden.

Den strukturelle beskæftigelse (renset for konjunkturer) antages at stige med 15.000 personer fra 2007 til 2015. Stigningen skal ses i lyset af allerede vedtagne reformer af arbejdsmarkedet samt 2015-planens krav til nye initiativer som øger beskæftigelsen. Ledighedens strukturelle niveau antages at falde fra omkring $5 \%$ af arbejdsstyrken i 2007 til $4 \%$ i 2010.

Bidraget til beskæftigelsen fra reformer mv. opvejer derved befolkningsudviklingens nedadgående pres på arbejdsstyrken.

Efter 2008 er det forudsat, at konjunkturerne gradvist normaliseres frem mod 2011, hvorefter konjunkturerne antages neutrale. I den sammenhæng er der forudsat et fald i den faktiske beskæftigelse frem mod 
2011, som følge af at konjunkturbidraget til beskæftigelsen gradvist falder bort.

De nuværende store overskud på den offentlige saldo forventes at blive gradvist mindre frem mod 2015. I 2015 ventes et overskud på de offentlige finanser på knap $1 / 2 \%$ af BNP. De aftagende overskud skal ses i lyset af navnlig en normalisering af konjunkturerne, faldende Nordsøindtægter og stigende udgifter til folkepension mv.

De offentlige overskud betyder en fortsat nedbringelse af den offentlige gæld. Forløbet frem mod 2015 indebærer, at ØMU-gælden nedbringes fra $30 \%$ af BNP i 2007 til omkring $15 \%$ af BNP i 2015, og at nettogælden vendes til et nettotilgodehavende.

Tabell 2.1 Nyckeltal för Danmarks ekonomi. Procentuell förändring. ${ }^{1)}$

\begin{tabular}{|c|c|c|c|c|}
\hline & $\begin{array}{r}\text { Mdr. kronor } \\
2006\end{array}$ & 2006 & 2007 & 2008 \\
\hline \multicolumn{5}{|l|}{ Fasta priser } \\
\hline Hushållens konsumtionsutgifter & 711,2 & 3,1 & 2,2 & 1,6 \\
\hline Offentliga konsumtionsutgifter & 356,0 & 1,5 & 1,8 & 1,7 \\
\hline Fasta bruttoinvesteringar & 339,0 & 13,0 & 3,0 & 0,7 \\
\hline Näringsliv & 216,6 & 13,5 & 5,2 & 1,9 \\
\hline Bostäder & 93,4 & 12,0 & 3,0 & $-3,0$ \\
\hline Myndigheter & 28,1 & 13,1 & $-12,5$ & 5,2 \\
\hline Lagerinvesteringar $^{2)}$ & 10,5 & 0,4 & 0,0 & 0,1 \\
\hline Total inhemsk efterfrågan & 1414,1 & 5,2 & 2,3 & 1,5 \\
\hline Export & 774,1 & 10,1 & 4,9 & 3,0 \\
\hline Import & 765,3 & 14,4 & 5,7 & 3,5 \\
\hline Bruttonationalprodukt & 1431,9 & 3,5 & 2,0 & 1,3 \\
\hline Sysselsättning, 1000 personer & . & 2,0 & 1,7 & 0 \\
\hline Arbetslöshet (\% av arbetskraften, DK-def.) & . & 4,3 & 3,3 & 3,1 \\
\hline Konsumtionsprisindex & . & 1,9 & 1,8 & 2,5 \\
\hline Lön ${ }^{3)}$ & . & 3,5 & 4,6 & 4,7 \\
\hline Effektiv valutakurs ${ }^{4)}$ & . & 0,0 & 1,3 & 0,2 \\
\hline Bytesförhållande, varor & . & $-0,2$ & 0,3 & 0,3 \\
\hline Bytesbalans (\% av BNP) & . & 2,4 & 1,7 & 1,3 \\
\hline 3-månaders penningmarknadsränta (nivå) & . & 3,2 & 4,4 & 4,8 \\
\hline
\end{tabular}

1) Beräknat i foregående års priser.

2) Förändring i procent av föregående års BNP.

3) Timlön för privat anställda, DA-løn.

4) Negativt tal innebär depreciering.

Källa: Økonomisk Redegørelse, august 2007. 


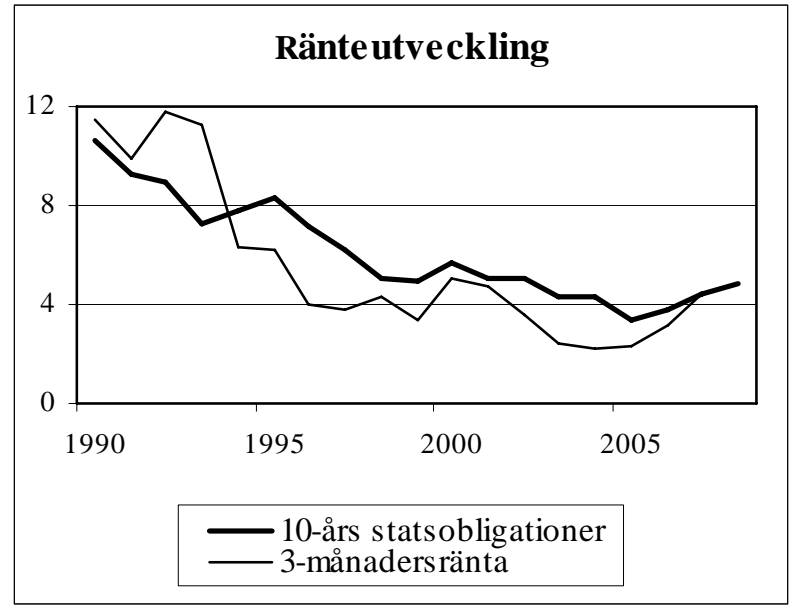

Figur 2.1 Korta och långa nominella räntor, procent

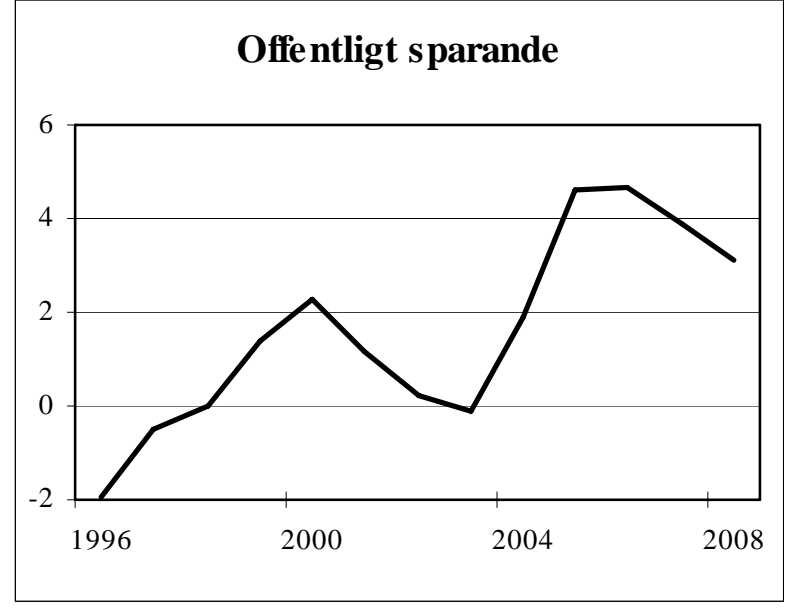

Figur 2.2 Det offentliga finansiella sparandet, \% av BNP.

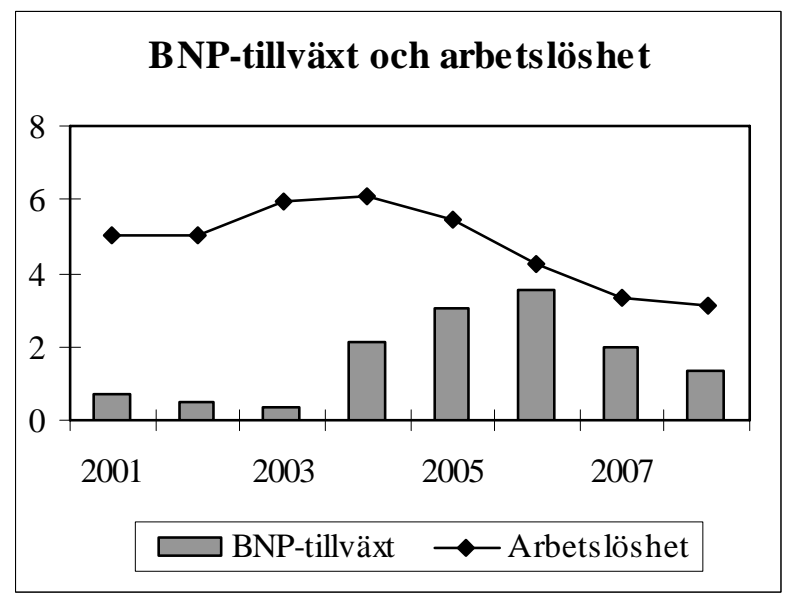

Figur 2.3 BNP-tillväxt och arbetslösheten, \% förändring. 


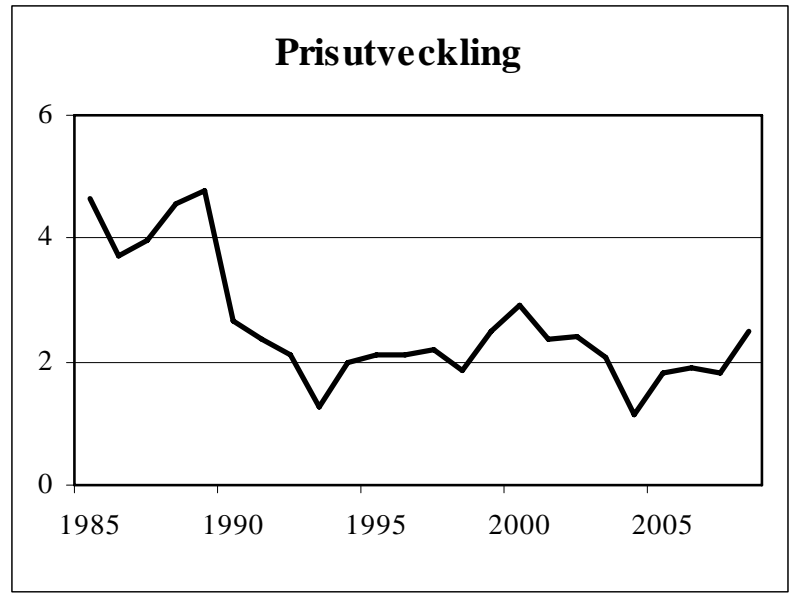

Figur 2.4 Konsumentprisindex

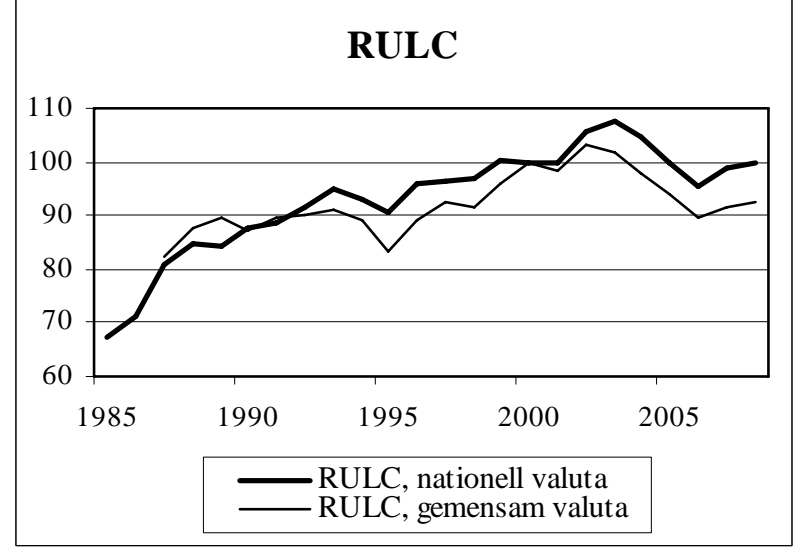

Figur 2.5 Relativ lönekostnad per producerad enhet

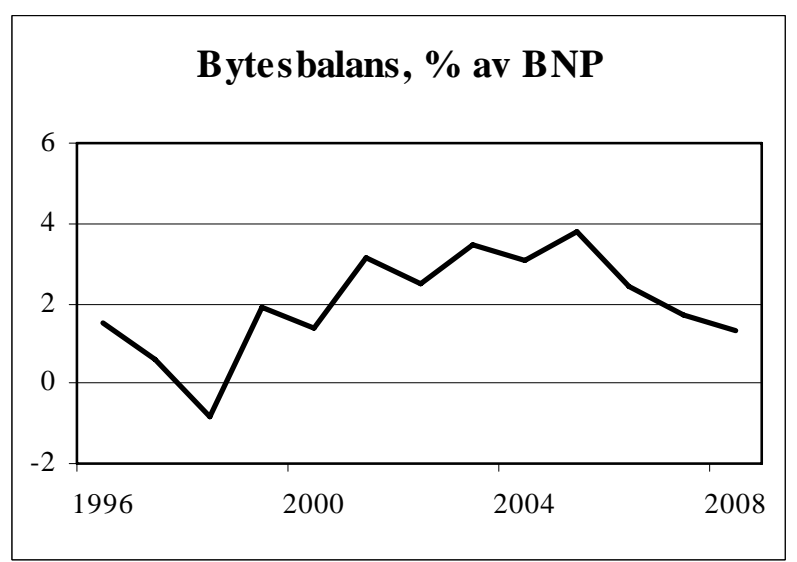

Figur 2.6 Bytesbalans, procent av BNP. 



\section{Finland}

\subsection{Den ekonomiska politiken}

Den ekonomiska politiken i Finland har under de senaste åren stött den ekonomiska tillväxten och sysselsättningen genom skatteåtgärder och anslagsökningar som förbättrar förutsättningarna för ekonomisk tillväxt och strukturella reformer för att kunna stå emot det utgiftstryck på den offentliga ekonomin som beror på befolkningens stigande medelålder. Målet för den nuvarande regeringens ekonomiska politik är att upprätthålla en stark ekonomisk tillväxt så att man med hjälp av en målmedveten sysselsättningspolitik kan skapa 80 000-100 000 nya arbetsplatser före utgången av nästa valperiod. En så kraftig ökning av sysselsättningen förutsätter åtgärder som främjar utbudet på arbetskraft och ökar produktiviteten. Politiken läggs särskild vikt vid att lindra matchningsproblemen på arbetsmarknaden.

Finanspolitiken stödde den ekonomiska tillväxten under åren med svag ekonomisk tillväxt i början av innevarande decennium i huvudsak med skattelättnader. Under 2006 och 2007 antas totalproduktionen har nått sin potentiella nivå och beräknas hålla sig så också även de närmaste åren. Finanspolitiken blir i år närmast neutral, trots de omfattande lindringarna av löneinkomstskattningen. År 2008 genomförs en moderat lindringen av beskattningen av arbete med 330 miljoner euro, men i helheten den offentliga ekonomin stöder ekonomiska tillväxten.

Regeringens mål är att strukturellt, dvs. konjunkturutvecklingen oberoende, överskott i statsfinanserna som motsvarar en procent av bruttonationalprodukten i slutet av valperioden 2001. Ökningen av de offentliga utgifterna dämpas genom den utgiftsram som sträcker sig över valperioden samt genom ökad produktivitet med hjälp av kommun- och servicestrukturreformen och statens produktivitetsprogram.

Regeringens viktigaste skattepolitiska mål ar att främja sysselsättningen genom att lindra beskattningen av arbete; öka arbetskraftens rörlighet och förbättra matchningen på arbetsmarknaden; göra beskattningen rättvisare; främja företagsamhet, kompetens, inhemsk ägande och sparande; betona miljöaspekter; och bekämpa verksamhet i den ekonomiska gråzonen.

Den offentliga ekonomins finansiella situation förstärks i år, och överskottet stiger till $4 \frac{1}{2} \%$ i förhållande till bruttonationalprodukten, varifrån det nästa år sjunker med en halv procentenhet. Både skatterna och utgifter sjunker kännbart i förhållande till bruttonationalprodukten i år, men nästa år sjunker endast skattesatsen något. Skuldsättningen fortsätter att minska med cirka 3 procentenheter om året och är nästa år $33 \%$ av bruttonationalprodukten. Statsfinanserna uppvisar i år ett överskott, 
nästa år minskar överskottet något. Kommunalekonomin förbättras också och är nästan i balans. Överskottet i socialskyddsfonderna är oförändrat. Arbetspensionsfondernas växande placeringsstock utgjorde i slutet av juni cirka 123 miljarder euro, vilket är $70 \%$ av totalproduktionen.

\subsection{Den ekonomiska utvecklingen}

Den ekonomiska tillväxten i Finland passerar i år konjunkturcykelns snabbaste fas. Totalproduktionen fortsatte att öka snabbt under första hälften av 2007 och produktionen under hela året överstiger fjolårets nivå med 41/2 \%. På samma sätt som 2006 stöder både nettoexporten och den inhemska efterfrågan tillväxten men tyngdpunkten förskjuts ändå till den inhemska efterfrågan. Exporten och investeringarna ökar med cirka $5 \%$ och hushållens konsumtionsutgifter med $4 \%$.

Industriproduktionen fortsätter att öka raskt i år, med 7 \%. Efterfrågan på framför allt traditionella metallindustriprodukter är rekordlivlig, medan tillväxten inom skogsindustrin är lamare. De kraftig internationaliserade teknologiindustriföretagens funktioner växer kännbarast utomlands. Byggbranschen är delvis överhettad och produktionsökningen i branschen börjar nå den övre gränsen i förhållande till produktionsmöjligheterna. Tjänsteproduktionen fortsätter att öka i jämn takt.

Högkonjunkturen fortsätter in på 2008. Den internationella efterfrågan förutspås vara fortsatt rask, men den tilltagande osäkerheten på finansmarknaden kan om den fortsätter ha även överraskande effekter på utvecklingen. Orderstocken ligger fortfarande på hög nivå inom bl.a. metallindustrin och byggandet, men utbudsbegränsningar dämpar produktionsökningen. När det gäller hushållens bostadsköp är den snabbaste tillväxtfasen redan förbi, eftersom den höga skuldsättningsnivån i kombination med de ökade skuldskötselutgifterna och höga priserna begränsar bostadsköpen. Köpkraftens och sysselsättningens tillväxt stöder dock fortfarande konsumtionsefterfrågan. Företagens investeringar ökar, liksom de offentliga investeringarna. BNP-ökningen kommer även nästa år upp till nästan $3 \frac{1}{2} \%$, dvs. den genomsnittliga tillväxttakten under den pågående konjunkturcykeln.

Antalet sysselsatta ökar med nästan 50000 personer i år; tillväxter riktar sig i första hand till service- och byggbranscherna, men i någon mån också till industrin. Sysselsättningsgraden stiger till $70 \%$. Utbudet på arbetskraft fortsätter att öka, då äldre arbetstagare stannar kvar på arbetsmarknaden längre än tidigare och det större utbudet på arbetsplatser lockar människor till arbetsmarknaden. Antalet arbetslösa minskar i år med cirka 25000 personer och arbetslöshetsgraden sjunker till 6,7 \%. Den goda sysselsättningsutvecklingen fortsätter 2008, då sysselsättningsgraden stiger till 701/2\% och arbetslöshetsgraden sjunker till 6,3 \%. 
Arbetskostnaderna har ökat måttfullt de senaste åren, vilket har bidragit till att stöda ekonomisk tillväxt och förbättrad sysselsättning. År 2008 stiger lönerna klart snabbare i och med de nya inkomstavtalen. Även om förhöjningarna torde hålla sig inom lönsamhetens gränser för de branscher som redan ingått sina löneuppgörelser, finns det risk för att priskonkurrenskraften börjar försämras för andra branschers del om förhöjningsnivån blir allmän linje. Konsumentpriserna har i år stigit nästan en procentenhet snabbare och takten närmar sig $2 \frac{1}{2} \%$, närmast till följd av att bostadspriserna och boendekostnaderna stigit. Den genomsnittliga inflationen förblir så gott som oförändrad 2008. Inflationsfaktorerna relativa betydelse förändras dock något. Vid sidan av lönerna höjs prisnivån av förhöjningarna av de indirekta skatterna samt hälso- och sjukvårdsavgifterna, medan boendekostnaderna åter stiger långsammare.

År 2007 stiger löntagarnas realinkomster långsammare än senaste år, men lättnaderna i statens inkomstbeskattning i kombination med den stigande sysselsättningen ökar köpkraften. Nästa år ökar hushållens disponibla realinkomster igen något snabbare, men sparandet fortsätter att minska och skuldfinansieringen ökar. Tills vidare har ökningen av förmögenhetsvärdena motsvarat den ökade skuldsättningen, men riskerna för överskuldsättning håller på att öka. Hushållens finansiella underskott i förhållande till bruttonationalprodukten stiger till över 4 \%.

Som motvikt till hushållssektorn, som uppvisar ett underskott, är företagens inkomster ungefär 5 \% större än utgifterna i förhållande till bruttonationalprodukten; ungefär lika mycket som överskottet i bytesbalansen. Företagens lönsamhet stiger i år till en även historiskt sett hög nivå, och deras finansiella strukturer är starka på grund av den goda resultatutvecklingen som pågått i flera år. Nästa år börjar kostnadsökningen emellertid begränsa inkomstutvecklingen.

\subsection{Utsikterna på medellång sikt}

På medellång sikt utgör de ökade utbudsbegränsningarna inom ekonomin, i synnerhet det minskade utbudet på arbetskraft när befolkningen åldras, ett allt större hinder för ekonomisk tillväxt. Befolkningen i arbetsför ålder börjar minskar i slutet av årtiondet, och antalet 15-64-åringar förutspås minska med över 100000 personer fram till 2015. Antalet som hör till arbetskraften kan förväntas börja minska redan innan befolkningen i arbetsför ålder börjar minska, eftersom arbetslösheten redan nu till stor del är strukturell. Detta tillsammans med den demografiska förändringen kan leda till att de tillgängliga arbetskraftsresurserna krymper under de följande fem åren.

Produktionskapacitetens ringa tillväxt de senaste åren bidrar också till att dämpa produktionspotentialens ökning. Investeringsgraden har legat nästan oförändrad på nivån 18-19 \% av BNP de senaste 10 åren. Forsk- 
nings- och produktutvecklingsutgifterna samt investeringarna utomlands har förstärkt produktionsunderlaget. Omplaceringen av den internationella produktionen innebär dock att den inhemska produktionen anpassar sig till de nya förhållandena. Då arbets- och kapitalinsatsen utvecklas dåligt kommer den ekonomiska tillväxten under de närmaste åren i huvudsak att stöda sig på produktivitetsökning. Produktivitetsökningen förväntas minska på medellång sikt till cirka $2 \%$ när antalet arbetsplatser minskar inom sådan industri där produktiviteten är högre och öka inom servicebranscherna där produktiviteten är lägre.

Ekonomins tillväxttakt på medellång sikt dämpas av utbudsbegränsningarna och detta skapar inte förutsättningar för en fortsatt sysselsättningsökning i samma takt som under de senaste åren. Regeringsprogrammets omnämnande av en sysselsättningsökning på 80-100 000 personer förutsätter vid sidan av en gynnsam internationell ekonomisk utveckling dessutom ekonomiskpolitiska åtgärder för att utöka ekonomins produktionspotential och minska den strukturella arbetslösheten.

Tabell 3.1 Nyckeltal för Finlands ekonomi. Procentuell förändring. ${ }^{1)}$

\begin{tabular}{|c|c|c|c|c|}
\hline & $\begin{array}{r}\text { Mdr. euro } \\
2006\end{array}$ & 2006 & 2007 & 2008 \\
\hline \multicolumn{5}{|l|}{ Fasta priser } \\
\hline Hushållens konsumtionsutgifter & 78 & 3,2 & 2,4 & 2,6 \\
\hline Offentliga konsumtionsutgifter & 34 & 1,6 & 1,7 & 1,4 \\
\hline Fasta bruttoinvesteringar & 28 & 5 & 2 & 1,6 \\
\hline Näringsliv & 16 & 4,1 & 3,2 & 3,1 \\
\hline Bostäder & 7 & 7,4 & 3 & 0,9 \\
\hline Myndigheter & 5 & 2,1 & -4 & $-1,8$ \\
\hline Lagerinvesteringar $^{2)}$ & 2 & 0,2 & 0 & $-0,1$ \\
\hline Total inhemsk efterfrågan & 142 & 3,5 & 2,2 & 2 \\
\hline Export & 57 & 5,6 & 3,8 & 6 \\
\hline Import & 49 & 6 & 4,4 & 3,5 \\
\hline Bruttonationalprodukt & 150 & 3,6 & 2,1 & 3,2 \\
\hline Sysselsättning, personer & . & 0 & 1,3 & 0,5 \\
\hline Arbetslöshet (\% av arbetskraften) & . & 8,8 & 8,2 & 7,5 \\
\hline Konsumtionsprisindex & . & 0,2 & 1 & 1,3 \\
\hline Lön ${ }^{3)}$ & . & 3,8 & 3,6 & 2,5 \\
\hline Effektiv valutakurs ${ }^{4)}$ & . & $-4,2$ & 0 & 0 \\
\hline Bytesförhållande & . & $-2,6$ & -4 & $-1,4$ \\
\hline Bytesbalans ( $\%$ av BNP). & . & 4,1 & 2,5 & 3,1 \\
\hline 3-månaders penningmarknadsränta (nivå) & $\ldots$ & 2,1 & 2,2 & 2,4 \\
\hline
\end{tabular}

1) Beräknat i fasta priser, basår 2000.

2) Förändring $i \%$ av föregående års BNP.

3) Löneindex.

4) Positivt tal innebär depreciering

Källor: Statistikcentralen och Finansministeriets ekonomiska avdelning. 


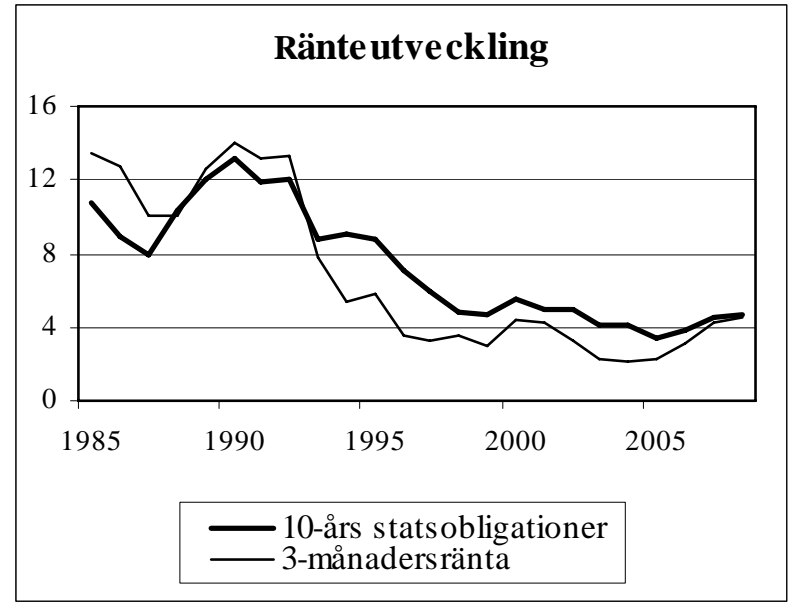

Figur 3.1 Korta och långa nominella räntor, procent

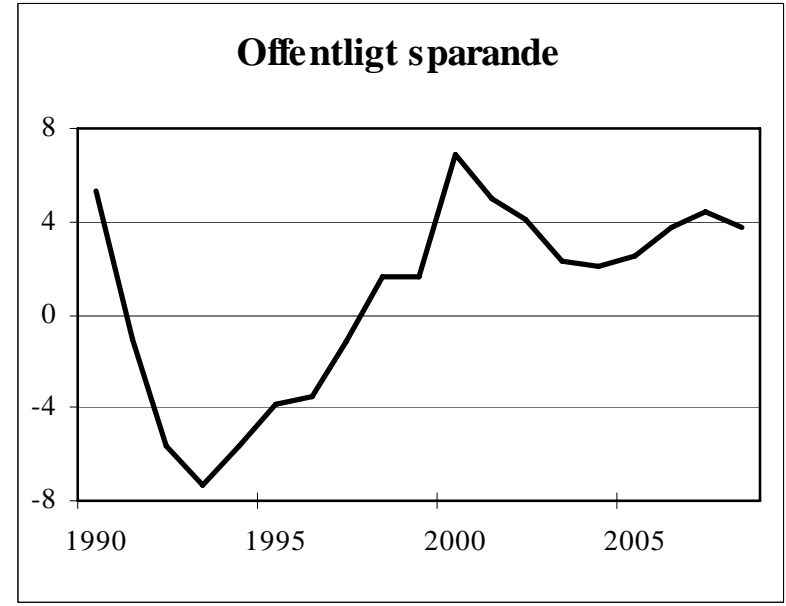

Figur 3.2 Det offentliga finansiella sparandet, \% av BNP.

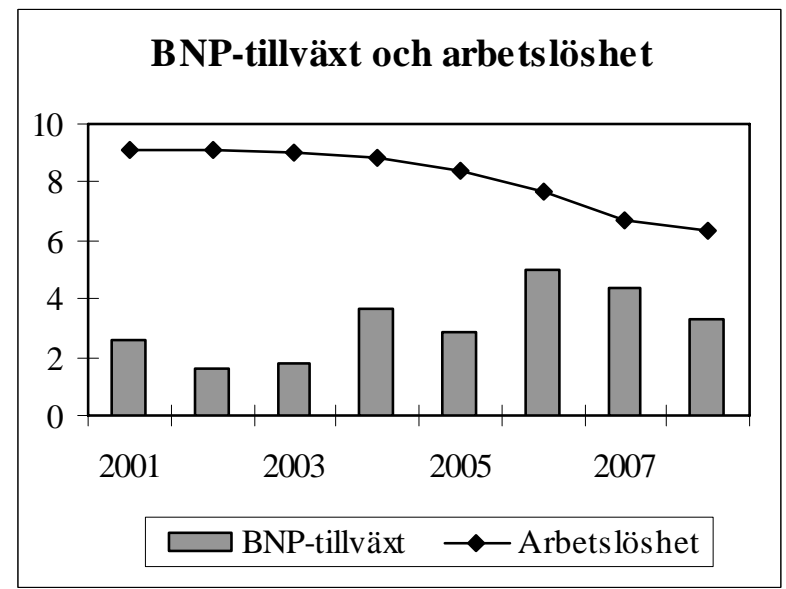

Figur 3.3 BNP-tillväxt och arbetslösheten, \% förändring. 


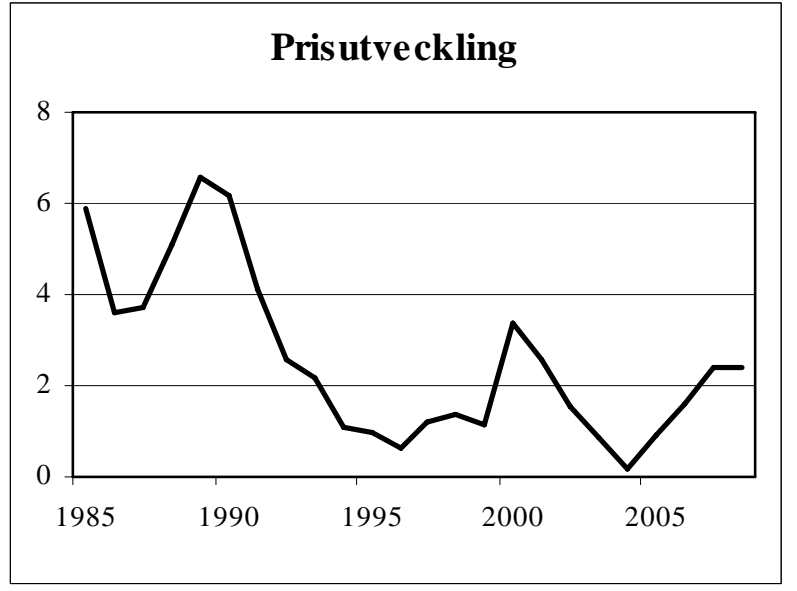

Figur 3.4 Konsumentprisindex

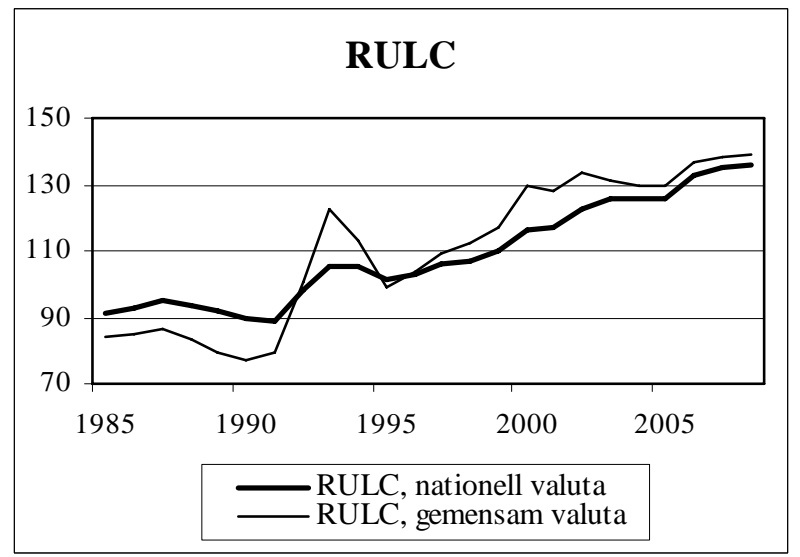

Figur 3.5 Relativ lönekostnad per producerad enhet.

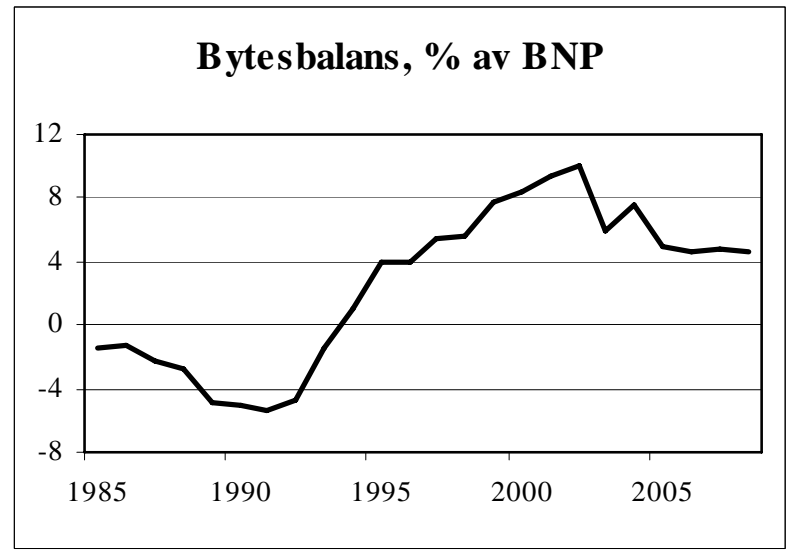

Figur 3.6 Bytesbalans, procent av BNP. 


\section{Island}

\subsection{Den økonomiske politik}

Den økonomiske politiks overordnede mål er at bevare makroøkonomisk stabilitet og dermed skabe en sund forudsætning for økonomisk vækst. Regeringens handlinger, hvad angår finans- og pengepolitik, er præget af denne målsætning, samtidigt med at erhvervslivets konkurrenceevner skal styrkes. Denne politik har bl. andet manifesteret sig i form af liberalisering indenfor finansmarkedet, privatisering af offentlige virksomheder og sænkning af personlig indkomstskat og selskabsskat. Resultatet har været kraftig økonomisk vækst i de sidste år, som både skyldes vækst indenfor de privatiserede brancher, især indenfor det finansielle marked, og stordrifts investeringer.

Statsbudgetens overskud i højkonjunkturen 1997-2001 og statens indkomst fra privatisering af offentlige selskaber var i stor grad anvendt til at nedbetale statsgælden som forbedrer mulighederne for skattesænkninger i fremtiden, samtidigt med at statskassen er i bedre stand til at klare sig i gennem lavkonjunktur perioder. Ifølge finansministeriets nye prognose, vil der være overskud på statsbudgettet i dette år på 3,4 \% af BNP. Dette er på trods at det personlige indkomstskatsniveau blev sænket om $1 \%$ og det personlige skattefradrag blev øget om 10,75 \% i januar 2007. I år 2008 er der til gengæld udsigt for et overskud på budgettet på 8,4 mia. ISK, hvilket udgør omkring 0,6 \% af BNP.

Statens netto gæld forventes at stige fra 3,8 \% af BNP i år 2006 til 4,9 \% i år 2008 men det burde ses i sammenhæng med at i år 2004 udgjorde statens netto gæld $17,8 \%$ af BNP.

I marts 2001 fik Centralbanken fuld selvstændighed og bankens rolle i den økonomiske politik blev mere gennemskuelig, hvor pengepolitikken skulle være indrettet efter inflations målsætning. Målsætningen er at inflationen skal være $2,5 \%$ på årsbasis med $\pm 1,5 \%$ tolerance interval. I 2004 begyndte inflationen at stige da huspriserne steg kraftigt efter markante ændringer på boliglånsmarkedet og indenlandsk efterspørgsel begyndte at vokse som følge. Centralbanken har siden da hævet styringsrenten, som nu er 13,3 \%. Inflationen steg videre i år 2006 som følge af fald i den islandske krones kurs. Inflationen måltes højst i august, hvor inflationen på årsbasis var 8,6 \%. Inflationen forventes at falde forholdsvis hurtigt i de næste måneder, så den reelle styringsrente har steget kraftigt i de sidste måneder. Der forventes dog ikke at Centralbanken vil begynde at nedsætte styringsrenten indtil den sidste del af år 2007. 


\subsection{Den økonomiske udvikling}

Den økonomiske vækst tog fart igen i år 2003 efter en mild recession i 2002. Et relativt stort investeringsprojekt har været i gang fra år 2003. Projektet indeholder bygning af en aluminiumfabrik med produktionskapacitet på 346 tusind ton per år. I tilæg til aluminiumfabrikken har været tilhørende investeringer i vandkraftsanlægninger. Projektet vil pågå indtil år 2008. Disse investeringer har medført spænding i økonomien som har præget udviklingen i de sidste år. Det har dog været flere faktorer som har gjort sig gældende i den økonomiske udvikling, som ændringer på boliglånmarkedet og udenlandske udgivelser af obligationer i islandske kroner. Disse faktorer især påvirkede husholdningernes købekraft, i og med at boligernes værdi steg kraftigt især i 2005, husholdningernes lånemuligheder var forbedret midlertidigt og importpriser var lave p.g.a. kronens stærke kurs. Dette medførte endnu større ubalance i udenrigshandelen, som i forvejen var stor p.g.a. import af investeringsgoder. Belatingsbalancen er estimeret at have været negativ på det der svarer til 25,7 \% af BNP i 2006.

Som følge af stigende ejendomspriser, boliginvesteringer tog også taget fart i de sidste par år. Dette har også bidraget til stærk indenlandsk efterspørgsel, hvilket har medført spænding på arbejdsmarkedet. Den gennemsnitlige registrerede arbejdsløshed i 2006 var 1,3\% af arbejdsstyrken. Dette fortæller kun en del af historien, da flytning af udenlandsk arbejdskraft til Island har aldrig før været så stor som i de sidste år. Den store efterspørgsel for arbejdskraft har bidraget til stækre lønstigninger. Islands statistiks lønindeks viser en stigning i timeløn på 9,6\% i 2006. Sammen med lønstigninger har nedsætning af indkomstskat blandt flere faktorer bidraget til en stigning i den disponible indkomst købekraft, som er estimeret at har været 8,5 \% i 2006, hvor kapitalindkomst har spillet en stigende rolle.

Ifølge finansministeriets prognose vil den økonomiske vækst være 0,7 \% i 2007. Næste år førventes væksten at være 1,2 \% og 2,1 \% i år 2009. Den økonomiske vækst forventes dermed at blive positiv i de næste år, selvom den indenlandske efterspørgsel forventes at blive svagere, især p.g.a. lavere investering, men også faldende privat forbrug. Den økonomiske vækst i de næste år vil derfor være drevet at forbedring i betalingsbalancen, hvor både importen mindskes og eksporten øges. Arbejdsløsheden forventes at være 1,1 \%, 2,9 \% og 3,6 \% i årene 2007, 2008 og 2009, henholdsvis. Finansiministeriet forventer at Centralbankens inflationsmål vil ikke opnås før 2009. Forudsætingerne for disse prognoser indebærer ikke videre stordriftsinvesteringer, selvom sandsynligheden for at der vil investeres videre i stordrift er til stede. Valutakursen forventes at være 118,8 indeks point i 2007, 119,3 i 2008 og 124,5 i 2009, som bregrundes hovedsageligt med at Centralbankens styringsrente forventes 
at bevares høj i 2007 og 2008 (13,3 \% og 11,8 \% hhv.) før renten vil være vil komme ned til 6,8 \% i $2009^{1}$.

Tabell 4.1 Nyckeltal för Islands ekonomi. Procentuell förändring ${ }^{1)}$

\begin{tabular}{|c|c|c|c|c|}
\hline & $\begin{array}{r}\text { Mdr. kronor } \\
2006\end{array}$ & 2006 & 2007 & 2008 \\
\hline \multicolumn{5}{|l|}{ Fasta priser } \\
\hline Hushållens konsumtionsutgifter & 686,5 & 4,6 & $-0,1$ & $-0,3$ \\
\hline Offentliga konsumtionsutgifter & 280,7 & 2,9 & 2,8 & 2,5 \\
\hline Fasta bruttoinvesteringar & 365,6 & 13 & $-24,1$ & -14 \\
\hline Näringsliv & 255,6 & 13,8 & $-35,3$ & $-32,9$ \\
\hline Bostäder & 74,8 & 17,2 & -5 & 0 \\
\hline Myndigheter & 35,1 & 0,8 & 16,3 & 45,2 \\
\hline Lagerinvesteringar $^{2)}$ & 13,3 & 1,1 & -1 & 0 \\
\hline Total inhemsk efterfrågan & 1346,1 & 7,4 & $-6,7$ & $-2,8$ \\
\hline Export & 372,2 & $-5,6$ & 11,5 & 11,7 \\
\hline Import & 576,5 & 8,8 & $-11,5$ & $-3,7$ \\
\hline Bruttonationalprodukt & 1141,7 & 2,6 & 0,9 & 2,9 \\
\hline Sysselsättning, personer & . & 156,7 & 157,5 & 155,3 \\
\hline Arbetslöshet (\% av arbetskraften) & . & 1,3 & 1,8 & 3,2 \\
\hline Konsumtionsprisindex & . & 6,8 & 3,6 & 2,5 \\
\hline Lön ${ }^{3)}$ & . & 9,6 & 7 & 4 \\
\hline Effektiv valutakurs ${ }^{4)}$ & . & 11,7 & 1,6 & 3,1 \\
\hline Bytesförhållande & . & 1,3 & 0 & $-0,4$ \\
\hline Bytesbalans (\% av BNP). & $\ldots$ & $-26,7$ & $-15,8$ & $-9,9$ \\
\hline 3-månaders penningmarknadsränta (nivå) & . & 11,9 & 13,3 & 12,2 \\
\hline $\begin{array}{l}\text { l) Beräknat i fasta } 2000 \text {-priser. } \\
\text { 2) Förändring i procent av föregående års BNP. } \\
\text { 3) Antal } 1000 \text {-årsverk. } \\
\text { 4) Timlön. } \\
\text { 5) Positivt tal innebär depreciering. } \\
\text { Källor: Statistik Island och Finansdepartementet. }\end{array}$ & & & & \\
\hline
\end{tabular}

\subsection{Udsigterne på mellemlangt sigt}

Finansministeriet har gjort prognoser for perioden 2008-2012. I sagens natur er den slags prognoser altid præget af en stor usikkerhed. Resultatet genspægler hovedsageligt de forudsætnigner og det teoretiske grundlag som anvendes for fremrengingen. Trods dette kan resultatet give en forestilling om fremtiden og dermed eventuellt blive en vejledining for den økonomiske politik.

Prognoserne viser at den årlige økonimsike vækst forventes at blive 1,9\% under perioden 2007-2012 sammenlignet med 5,4 \% over perioden 2003-2006. Over perioden 2003-2006 var den gennemsnittlige beta-

\footnotetext{
${ }^{1}$ Presentationen af styringsrenten er blevet ændret fra kumulativ rente til nominel rente. Selvom den nominelle rente er lavere end den kumulative, er der ikke tale om en egentlig nedsætning af renten.
} 
lingsbalance negativ på 14,5 \% af BNP men kommer til med at falde ned til 8,3 \% i perioden 2007-2012. Dette er baseret på forudsetninger om øget eksport og til dels en depreciering af valutakursen.

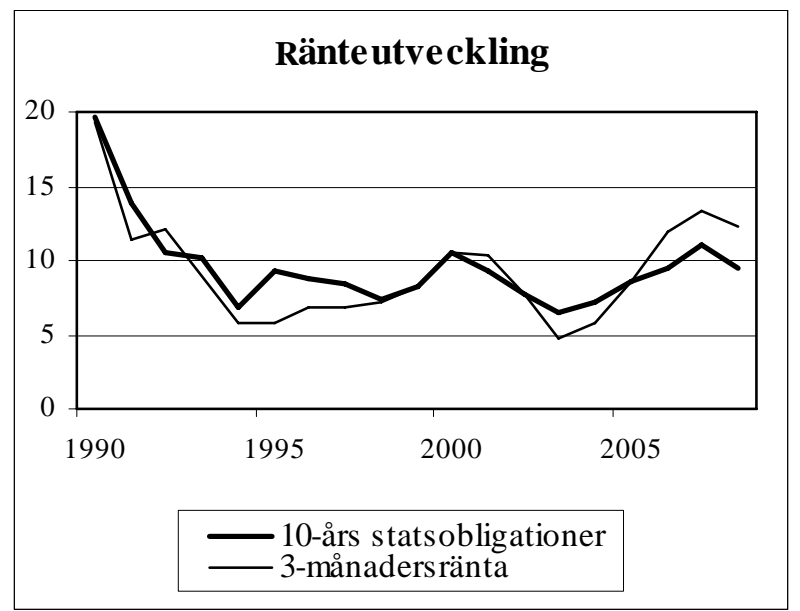

Figur 4.1 Korta och långa nominella räntor, procent.

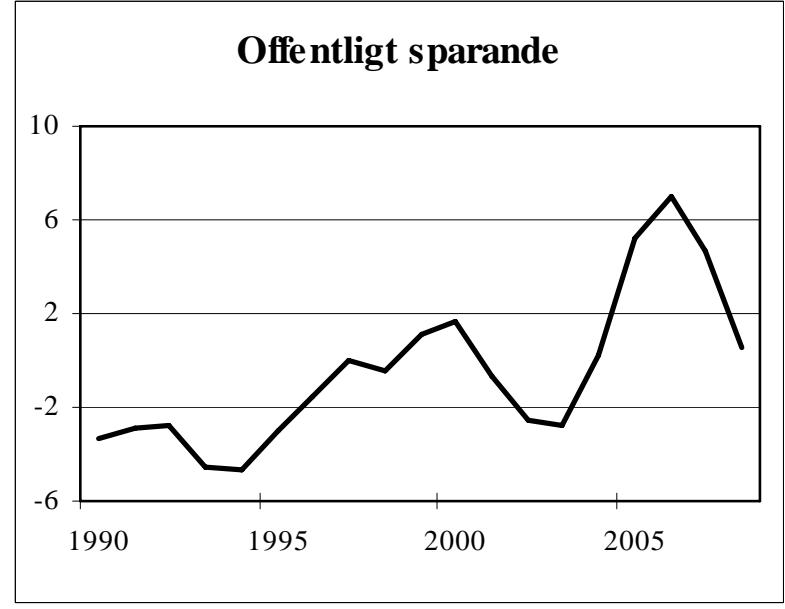

Figur 4.2 Det offentliga finansiella sparandet, \% av BNP.

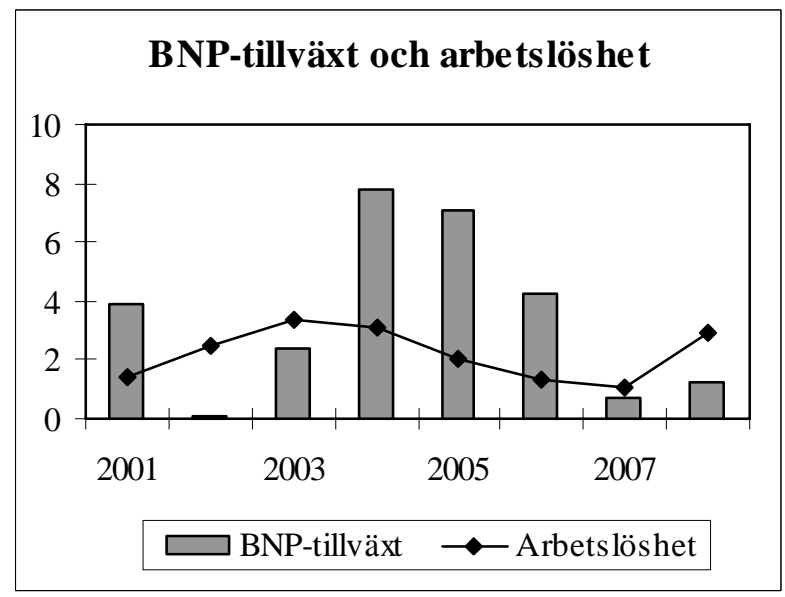

Figur 4.3 BNP-tillväxt och arbetslösheten, \% förändring 


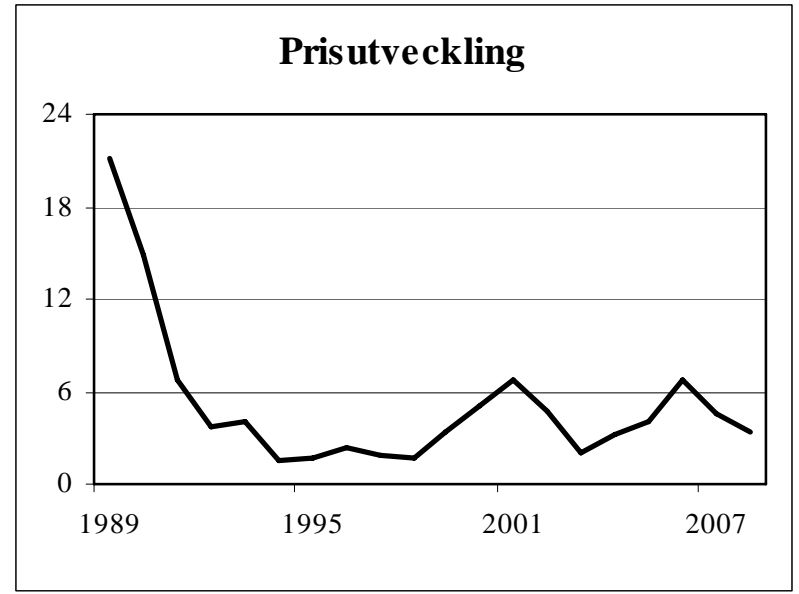

Figur 4.4 Konsumentprisindex.

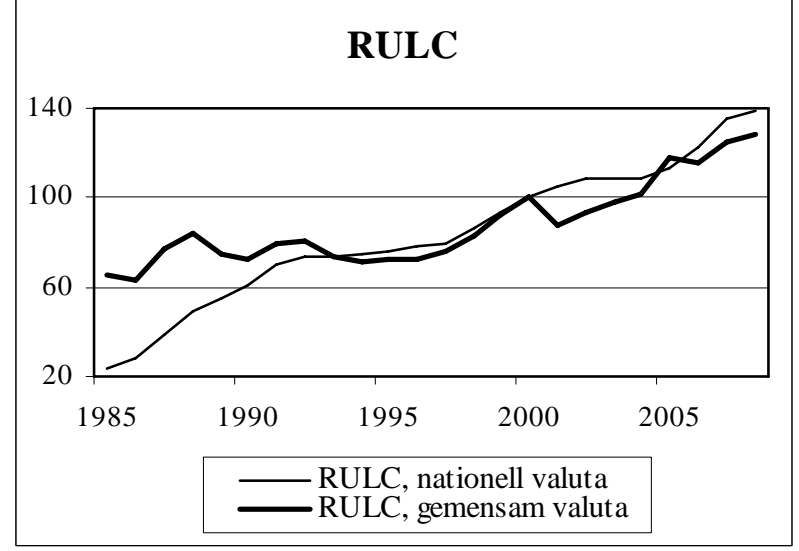

Figur 4.5 Relativ lönekostnad per producerad enhet

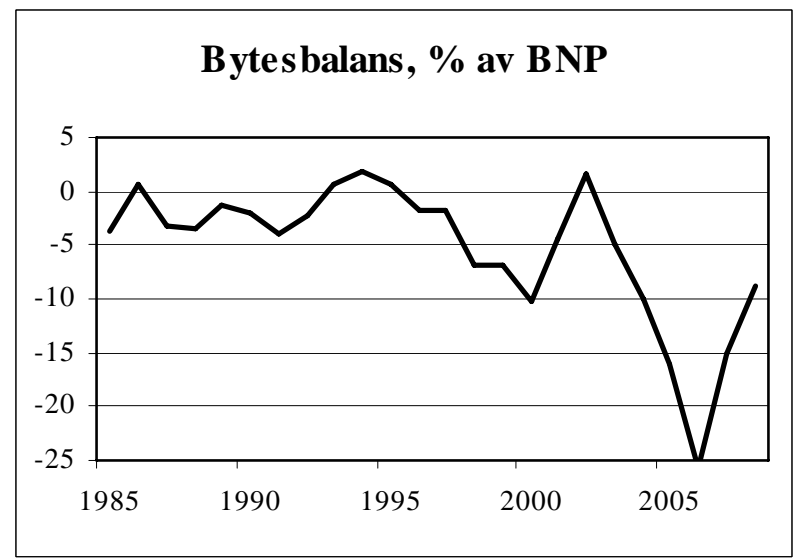

Figur 4.6 Bytesbalans, procent av BNP.

Källor: Statistik Island och Finansdepartementet. 



\section{Norge}

\subsection{Den økonomiske politikken}

Den norske regjeringen vil føre en økonomisk politikk som legger til rette for arbeid til alle, fortsatt økonomisk vekst, en bærekraftig utvikling, en mer retteferdig fordeling og styrking av velferdsordningene. De ulike delene av den økonomiske politikken må virke sammen for å nå disse målene.

Finanspolitikken er lagt opp med utgangspunkt i retningslinjer som innebærer at petroleumsinntektene gradvis fases inn i norsk økonomi, om lag i takt med utviklingen i forventet realavkastning av Statens pensjonsfond - Utland (handlingsregelen). Budsjettpolitikken er dermed gitt en mellomlangsiktig forankring. Samtidig understreker retningslinjene at hensynet til en stabil økonomisk utvikling skal tillegges betydelig vekt $\mathrm{i}$ den løpende utformingen av budsjettpolitikken.

Pengepolitikken skal sikte mot stabilitet i den norske krones verdi, nasjonalt og i forhold til Norges handelspartnere. Den operative gjennomføringen av pengepolitikken skal rettes inn mot lav og stabil inflasjon, definert som en årsvekst i konsumprisene som over tid er nær 2,5 pst. Av forskriften følger det at pengepolitikken skal bidra til å stabilisere utviklingen i produksjon og sysselsetting og til stabile forventninger om valutakursutviklingen. Budsjett- og pengepolitikken må virke sammen for å bidra til en balansert utvikling i norsk økonomi.

Regjeringen legger opp til å holde bruken av petroleumsinntekter på et nivå som understøtter en fortsatt balansert utvikling i norsk økonomi, i overensstemmelse med de rammer handlingsregelen setter. Etter fire år med sterk vekst preges norsk økonomi av høy aktivitet og et stramt arbeidsmarked. Veksten i sysselsettingen har vært rekordhøy, arbeidsledigheten har falt til et svært lavt nivå, og lønnsveksten har tatt seg opp. Konjunktursituasjonen tilsier dermed at bruken av petroleumsinntekter øker langsommere enn forventet realavkastning av Statens pensjonsfond - Utland i 2008. I Nasjonalbudsjettet for 2008 (NB08) legges det opp til et strukturelt, oljekorrigert underskudd i 2008 på 76,8 mrd. 2008-Kroner. Dette er $7 \mathrm{mrd}$. kroner under forventet fondsavkastning og utgjør om lag 3,7 pst. av fondskapitalen ved inngangen til året. Forslaget innebærer en økning i det strukturelle, oljekorrigerte underskuddet på 5,4 mrd. kroner fra 2007 til 2008, målt i 2008-priser. Regnet som andel av trend-BNP for Fastlands-Norge er økningen $1 / 4$ prosentpoeng. Skatte- og avgiftsnivået holdes uendret. 


\subsection{Den økonomiske utviklingen}

Norsk økonomi er inne i en kraftig høykonjunktur. Siden våren 2003 har den årlige veksten i fastlandsøkonomien vært over $4 \frac{1}{2}$ pst. i gjennomsnitt. Veksten har vært bredt basert, med sterk oppgang i både vare- og tjenesteproduserende sektorer. Vi må helt tilbake til begynnelsen av 1970årene for å finne en tilsvarende sterk vekstperiode. Lave renter har bidratt til at husholdningenes etterspørsel har økt raskere enn deres inntekter. Også høye oljeinvesteringer og en svært gunstig utvikling i markedene for norsk eksport har bidratt til oppgangen i norsk økonomi. Sysselsettingen har etter hvert økt markert, og arbeidsledigheten har kommet ned på sitt laveste nivå på nesten 20 år. Samtidig melder stadig flere næringer nå om mangel på kvalifisert arbeidskraft, og lønnsveksten tiltar.

I NB08 anslås BNP-veksten i fastlandsøkonomien til 5 pst. i år, 11/4 prosentpoeng mer enn lagt til grunn i Revidert nasjonalbudsjett 2007 (RNB07). Anslaget innebærer at 2007 blir det fjerde året på rad med svært høy vekst. Framover legges det til grunn en utvikling der veksten i fastlandsøkonomien gradvis avtar ned mot trendvekst. I 2008 anslås veksten i BNP for Fastlands-Norge til 23/4 pst.

Den sterke veksten i verdiskapingen i fastlandsøkonomien gjenspeiles i arbeidsmarkedet. Foreløpige nasjonalregnskapstall viser at sysselsettingen økte med hele 72000 personer fra 2005 til 2006, og ifølge Statistisk sentralbyrås arbeidskraftundersøkelse var det i perioden mai-juli i år sysselsatt 84000 flere enn i samme periode i fjor. I NB08 anslås sysselsettingen å øke med 85000 personer i 2007 og 25000 personer i 2008. Anslaget for 2007 innebærer den sterkeste sysselsettingsveksten som noensinne er registrert i Norge.

En del av oppgangen i sysselsettingen de siste årene har et motstykke i tilstrømming av arbeidskraft til Norge fra andre land. Samtidig har det også vært betydelig vekst i den norske arbeidsstyrken. Yrkesdeltakelsen har økt klart, særlig blant eldre kvinner og ungdom. Arbeidsledigheten har falt til det laveste nivået siden slutten av 1980-tallet. I tremånedersperioden mai-juli i år utgjorde ledigheten 2,5 pst. av arbeidsstyrken, målt etter ILOs definisjon og justert for sesongvariasjoner. Det er 1,1 prosentpoeng lavere enn i samme periode i fjor, og nesten en halvering av ledigheten siden sommeren 2005. I NB08 er ledigheten anslått til 21/2 pst. av arbeidsstyrken som gjennomsnitt både for 2007 og 2008.

Lønnsveksten holdt seg lenge lavere i denne konjunkturoppgangen enn i tidligere oppgangsperioder. Høyt kostnadsnivå i deler av konkurranseutsatt sektor, økte muligheter for utflytting av norsk produksjon, lav prisvekst og økt tilbud av arbeidskraft fra de nye EU-landene er faktorer som trolig har virket modererende på lønnsveksten de siste årene. Arbeidsledigheten i år og neste år anslås i NB08 å bli klart lavere enn den var i høykonjunkturen på slutten av 1990-tallet. Høy kapasitetsutnytting kan gi kamp om ressursene. I en situasjon med god lønnsomhet i bedrif- 
tene kan dette slå ut i en sterkere lønns- og prisvekst framover enn det vi har sett hittil. Informasjon for inneværende år tyder på at lønnsveksten som steg fra 3,3 pst. i 2005 til 4,1 pst. i 2006 - nå tiltar ytterligere. I NB08 anslås årslønnsveksten til 5 pst. både i år og neste år. For inneværende år innebærer dette en oppjustering på $1 / 4$ prosentpoeng fra RNB07. Til sammenlikning anslås veksten i lønnskostnadene hos våre handelspartnere til 31/4 pst. i år og 33/4 pst. neste år.

Konsumprisveksten (KPI) har hittil i år holdt seg lav, særlig som følge av prisnedgang på elektrisitet. Prisene på importerte konsumvarer har fortsatt å falle, mens prisveksten på norskproduserte varer og tjenester har tatt seg opp. Konsumprisene økte med 0,4 pst. fra august i fjor til august i år, og med 1,8 pst. justert for avgiftsendringer og utenom energivarer (KPI-JAE). Det ser nå ut til at utviklingen i energiprisene vil trekke konsumprisveksten ned med 1 prosentpoeng i inneværende år, for deretter å trekke prisveksten opp igjen neste år. I NB08 anslås KPI å øke med 1/2 pst. i 2007 og 21/2 pst. i 2008. Veksten i KPI-JAE anslås å ta seg opp fra $1 \frac{1}{2}$ pst. i år til 2 pst. neste år. Forventningene om sterkere oppgang i KPIJAE neste år må bl.a. ses i sammenheng med at veksten i lønnskostnadene har økt.

\subsection{Utsiktene på mellomlang sikt}

I NB08 anslås veksten i fastlandsøkonomien til 41/2 pst. pr. år for årene 2004-2007. Dette er om lag 13/4 prosentpoeng over gjennomsnittet for perioden 1970-2006, som er anslått til 23/4 pst. Om lag 21/2 prosentpoeng av denne veksten kan føres tilbake til utviklingen i arbeidsproduktiviteten, mens $1 / 4$ prosentpoeng skyldes $ø$ kt arbeidsinnsats.

Produktivitetsveksten var høy i årene 2004 - 2006. Foreløpige nasjonalregnskapstall tyder imidlertid på en avdemping i produktivitetsveksten den siste tiden, slik en ofte ser når økonomien nærmer seg en konjunkturtopp. For fireårsperioden 2004-2007 anslås den gjennomsnittlige veksten i arbeidsproduktiviteten nå til rundt $2 \frac{1}{2}$ pst. pr. år, dvs. om lag som det historiske gjennomsnittet. For de siste fire årene sett under ett, kan dermed den unormalt sterke veksten i økonomien føres tilbake til en økning i arbeidsinnsatsen (målt i timeverk) på om lag 2 pst. pr. år. Nesten hele denne oppgangen i arbeidsinnsats kan føres tilbake til en vekst i antall sysselsatte personer på om lag 185000 personer gjennom perioden, hvorav anslagsvis 20 pst. kan tilskrives økt innvandring (både kortsiktig arbeidsinnvandring og annen innvandring). Det knytter seg usikkerhet til slike anslag.

Historisk sett er yrkesdeltakelsen nå høy i Norge, mens arbeidsledigheten er lav. Det trekker i retning av at rommet for vekst i timeverkene er svært begrenset, utover det som følger av den underliggende veksten i arbeidsstyrken på om lag 1/2 pst. pr. år. Videre kan konjunktursituasjonen 
tilsi en moderat produktivitetsvekst de nærmeste årene. Med en gjennomsnittlig produktivitetsvekst i fastlandsøkonomien på i størrelsesorden 13/4-2 pst. kan veksten i produksjonskapasiteten i Fastlands-Norge i årene fram mot 2012 anslås til 21/4-21/2 pst. pr. år.

I NB08 er avdempingen i veksten i fastlandsøkonomien fra 2007 til 2008 anslått å fortsette i perioden 2009-2012. Det ventes videre nedgang i veksten i privat konsum og i fastlandsinvesteringene, noe som bl.a. må ses i sammenheng med at pengemarkedsrentene anslås å stige ytterligere noe neste år. Videre ventes det nedgang i oljeinvesteringene gjennom perioden 2009-2012 sett under ett.

I tillegg til disse forholdene vil veksten i norsk økonomi avhenge av etterspørselsimpulsene fra budsjettpolitikken. I anslagene i NB08 er det teknisk lagt til grunn om lag samme impuls fra budsjettpolitikken i årene framover som anslått for 2008.

Tabell 5.1 Nyckeltal för Norges ekonomi. Procentuell förändring ${ }^{1)}$.

\begin{tabular}{|c|c|c|c|c|}
\hline & $\begin{array}{r}\text { Mdr. kronor } \\
2006\end{array}$ & 2006 & 2007 & 2008 \\
\hline \multicolumn{5}{|l|}{ Fasta priser } \\
\hline Hushållens konsumtion & 873,6 & 4,4 & 6,0 & 3,5 \\
\hline Offentlig konsumtion & 418,2 & 3,3 & 3,1 & 2,3 \\
\hline Fasta bruttoinvesteringar & 399,7 & 7,4 & 9,9 & 1,3 \\
\hline \multicolumn{5}{|l|}{ Varav: } \\
\hline Oljeverksamhet & 95,5 & 4,4 & 15,0 & 0,0 \\
\hline Fastlands-företag & 135,6 & 8,5 & 10,7 & 4,0 \\
\hline Bostäder & 92,2 & 6,5 & 6,0 & $-1,8$ \\
\hline Myndigheter & 58,3 & 9,1 & 8,6 & 2,0 \\
\hline Lagerinvesteringar $\left.{ }^{2}\right)$ & 67,4 & 0,5 & 0,0 & $-0,1$ \\
\hline Total inhemsk efterfrågan & 1758,9 & 5,2 & 6,0 & 2,5 \\
\hline Export (ex.skip, platformer og petroleum) & 271,5 & 5,9 & 8,0 & 4,3 \\
\hline Import & 609,7 & 8,2 & 8,3 & 3,8 \\
\hline Bruttonationalprodukt & 2151,7 & 2,8 & 3,5 & 3,1 \\
\hline Varav: Fastlands-Norge & 1563,2 & 4,6 & 5 & 2,8 \\
\hline Sysselsättning, personer & . & 3,1 & 3,5 & 1,0 \\
\hline Arbetslöshet (\% av arbetskraften) & . & 3,4 & 2,5 & 2,5 \\
\hline Konsumtionsprisindex & . & 2,3 & 0,6 & 2,6 \\
\hline Lön ${ }^{3)}$ & . & 4,1 & 5 & 5 \\
\hline Effektiv valutakurs ${ }^{4)}$ & . & 0,4 & $-0,8$ & $-0,2$ \\
\hline Bytesförhållande & . & 10,5 & $-3,5$ & $-3,3$ \\
\hline Bytesbalans (\% av BNP). & . & 16,4 & 13,0 & 11,4 \\
\hline 3-månaders penningmarknadsränta (nivå) & . & 3,1 & 4,8 & 5,9 \\
\hline
\end{tabular}

1) Beräknat i fasta priser, basår 2003.

2) Förändring i \% av föregående års BNP.

3) Årslön.

4) Positivt tal innebär depreciering

Källor: Statistisk sentralbyrå og Finansdepartementet. 
Med disse forutsetningene kan veksten i fastlandsøkonomien i årene 2009-2012 bli noe lavere enn trendveksten. Dette vil dempe presset på arbeidskraftressursene, og ledigheten vil kunne stige litt i årene framover. Ledigheten er likevel ventet å holde seg klart under gjennomsnittet for de siste 25 årene.

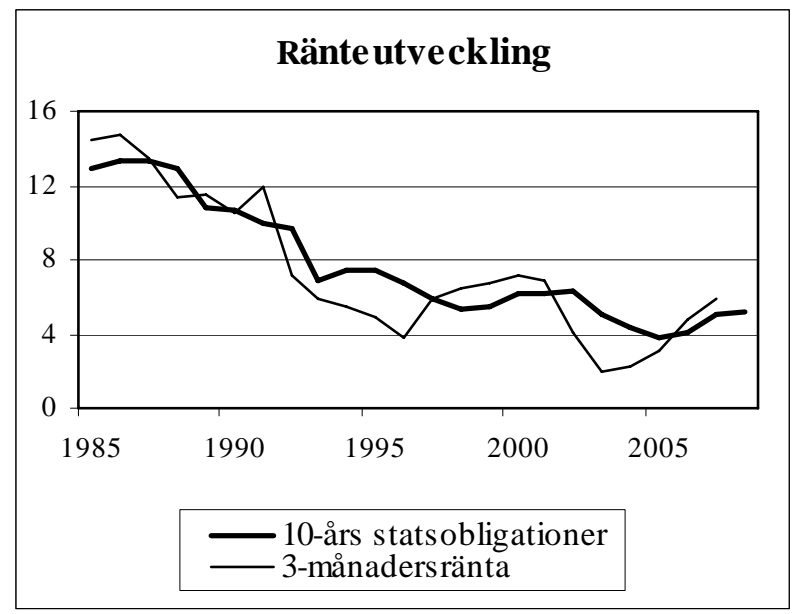

Figur 5.1 Korta och långa nominella räntor, procent.

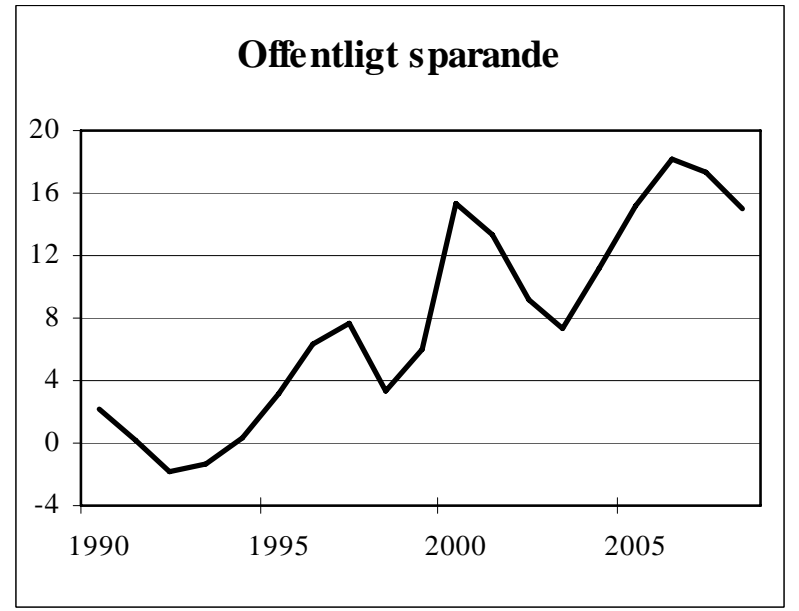

Figur 5.2 Det offentliga finansiella sparandet, \% av BNP. 


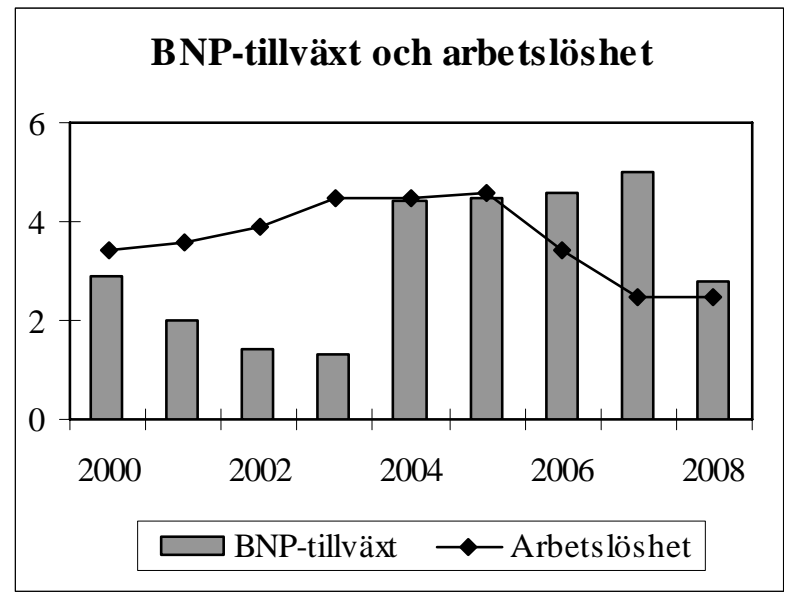

Figur 5.3 BNP-tillväxt och arbetslösheten, \% förändring

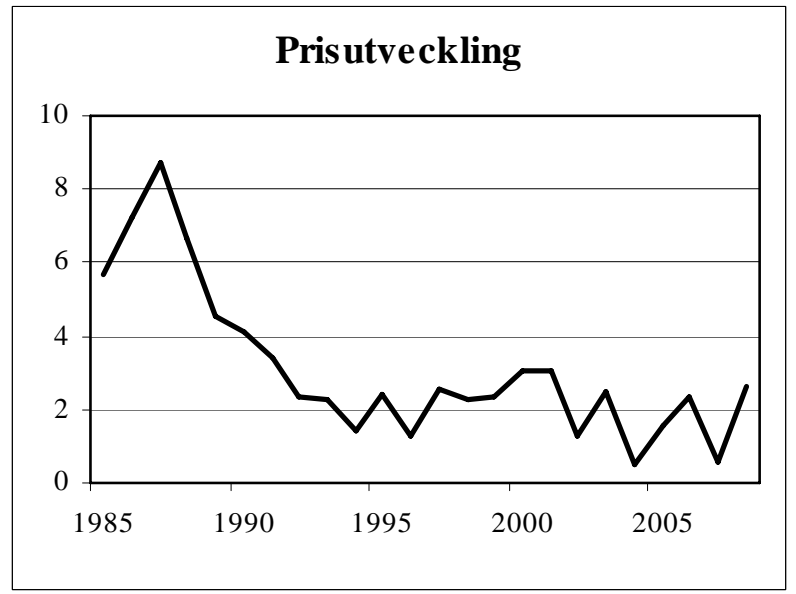

Figur 5.4 Konsumentprisindex.

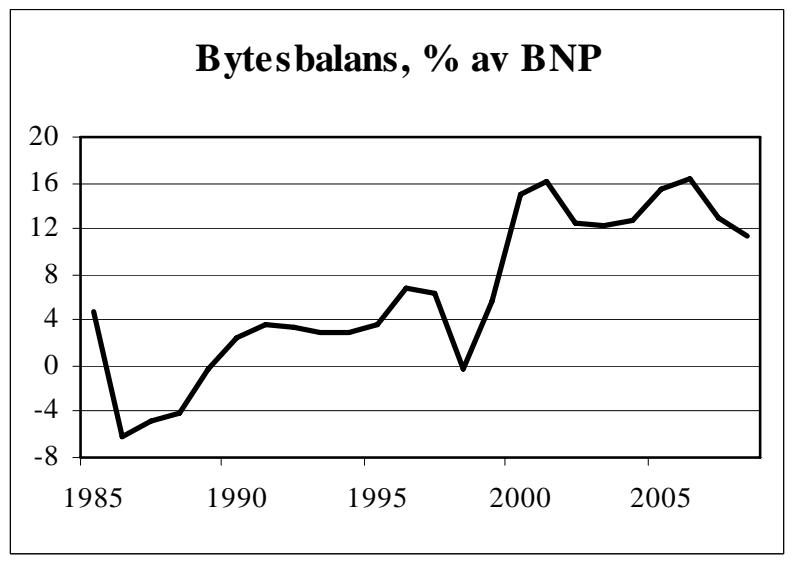

Figur 5.5 Bytesbalans, procent av BNP.

Källor: Statistisk sentralbyrå og Finansdepartementet. 


\section{Sverige}

\subsection{Den ekonomiska politiken}

Sveriges offentliga finanser fortsätter att utvecklas starkt och utvecklingen lever väl upp till stabilitets- och tillväxtpaktens krav. Det av riksdagen beslutade målet för den offentliga sektorns finansiella sparande sätter ramarna för finanspolitiken. Under våren 2007 justerades målet, efter beslut av Riksdagen, från ett överskott på 2 procent till 1 procent av BNP över konjunkturcykeln. Justeringen gjordes med anledning av Eurostats beslut att sparandet i premiepensionssystemet ska redovisas i nationalräkenskapernas hushållssektor i stället för som hittills i den offentliga sektorn. Enligt Budgetpropositionen 2008 (Prop 2007/08:1) var överskottet åren 2000-2006 i genomsnitt 1,1 procent av BNP och det bedöms i genomsnitt uppgå till 3,1 procent av BNP under perioden 2007-2010.

I 2007 års vårproposition utvecklade regeringen principerna för det finanspolitiska ramverket. Regeringen slog fast att målet för den offentliga sektorns finansiella sparande behöver upprätthållas under den nuvarande mandatperioden och så länge det är nödvändigt för att de offentliga finanserna ska utvecklas på ett långsiktigt uthålligt sätt. Ett överskott i enlighet med det fastlagda målet skapar en stabil grund för att möta de utmaningar som följer av den framtida ökningen av andelen äldre i befolkningen. Det fleråriga utgiftstakets främsta uppgift är att ge förutsättningar att uppnå överskottsmålet. Regeringen avser att tydligt ange vilka överväganden som ligger till grund för bedömningarna och förslagen rörande utgiftstakets nivå. I det sammanhanget ska bedömningar av bl.a. eftersträvade skattenivåer och risker och osäkerheter i de takbegränsade utgifternas utveckling beaktas. Regeringen avser också att i de ekonomiska vårpropositionerna göra en bedömning av och redovisa ett lämpligt utgiftstak för det tredje tillkommande året. Därmed säkerställs finanspolitikens medelfristiga perspektiv. Slutligen ska statsbudgeten utformas på ett sätt som är förenligt med de grundläggande principerna om fullständig bruttoredovisning.

Det finns inte något enskilt inflationsmått som i varje given tidpunkt alltid visar vilken penningpolitik som behövs. Penningpolitiken verkar med eftersläpning och inriktas normalt på att inflationsmålet skall uppnås inom två till tre år. Den tidshorisonten ger också utrymme att ta hänsyn till utvecklingen i den reala ekonomin. På det sättet förs en flexibel penningpolitik. Från och med 2007 redovisar Riksbanken också en prognos för reporäntan för att tydliggöra penningpolitiken. Inflationstrycket har gradvis börjat stiga från en mycket låg nivå och det underliggande inflationstrycket förväntas stiga relativt snabbt under 2008 och 2009 för att 
dämpas något 2010. I juni 2005 sänkte Riksbanken styrräntan till historiskt låga 1,5 procent. Därefter har Riksbanken successivt höjt styrräntan.

\subsection{Den ekonomiska utvecklingen}

Den svenska BNP-tillväxten väntas bli fortsatt hög 2007 och 2008. Varuexporttillväxten har bromsat in i år men återhämtar sig under 2008 då efterfrågan på svenska produkter i utlandet stärks på nytt. De senaste årens starka investeringstillväxt når sin topp i år. I takt med att den utbyggda produktionskapaciteten tas i anspråk och att räntelägret blir högre, förutses investeringarna växa långsammare 2008. Den inhemska efterfrågan blir trots detta god till följd av att hushållens konsumtion väntas växa kraftigt. Ökande sysselsättning, inkomstskattesänkningar, och en i utgångsläget god förmögenhetsställning väntas bidra till en hög konsumtionstillväxt, framför allt under 2008. Den offentliga konsumtionen ökar inom kommunsektorn och gynnas av starka kommunfinanser.

Sysselsättningen vände upp för två år sedan. Den har under det senaste året ökat i snabb takt, samtidigt som arbetslösheten minskat betydligt. Efterfrågan på arbetskraft är fortsatt stark, antalet nyanmälda lediga platser ligger på en hög nivå, och företagens anställningsplaner är positiva. Sysselsättningen fortsätter därför att stiga 2007 och 2008. Antalet arbetade timmar växer snabbt, framför allt i år, vilket innebär till att produktivitetstillväxten dämpas. Trots att de arbetsmarknadspolitiska programmen minskats kraftigt sedan slutet av 2006 har den öppna arbetslösheten fortsatt att sjunka. Både den öppna och totala arbetslösheten, dvs. summan av öppen arbetslöshet och personer i arbetsmarknadspolitiska program, fortsätter att sjunka under resten av 2007 och 2008.

\subsection{Utsikterna på medellång sikt}

På längre sikt är det svårt att förutsäga konjunktursvängningar. Beräkningarna för 2009 och 2010 grundar sig därför på bedömningar om hur stort resursutnyttjandet är samt på den potentiella tillväxttakten i ekonomin. År 2008 bedöms resursnyttjandet på arbetsmarknaden vara högt, trots att vidtagna reformer bl.a. på arbetsmarknadsområdet bidrar till ett ökat arbetskraftutbud. Det leder till att lönerna och inflationen ökar mer än vad som är förenligt med Riksbankens inflationsmål. Riksbanken höjer därför reporäntan till som högst 4,75 \% 2009. Höga arbetskraftskostnader och hög ränta leder till att tillväxten i dämpas och BNP ökar långsammare än potentiell BNP såväl 2009 som 2010. Sysselsättningen ökar endast marginellt under perioden och den öppna arbetslösheten stiger från 4,0 \% 2008 till 4,3 \% 2010. Den s.k. totala arbetslösheten, dvs. öppen ar- 
betslöshet inklusive andelen deltagare i arbetsmarknadspolitiska program, stiger till 6,2\%.

Tabell 6.1 Nyckeltal för Sveriges ekonomi. Procentuell förändring ${ }^{1)}$

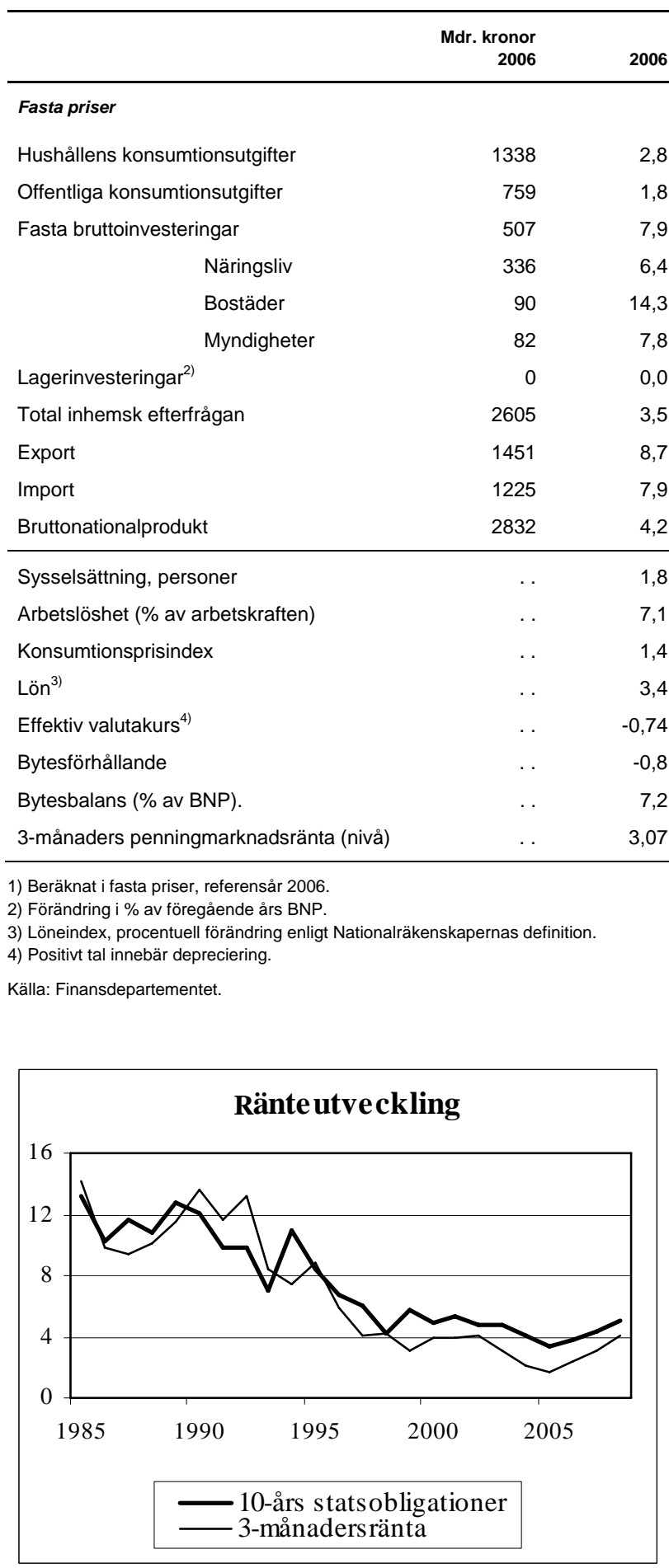

Figur 6.1 Korta och långa nominella räntor, procent. 


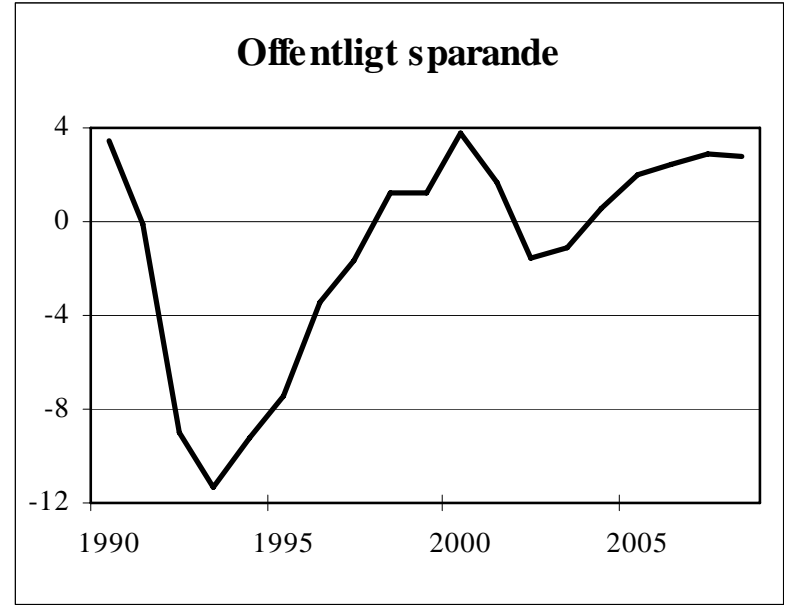

Figur 6.2 Det offentliga finansiella sparandet, \% av BNP.

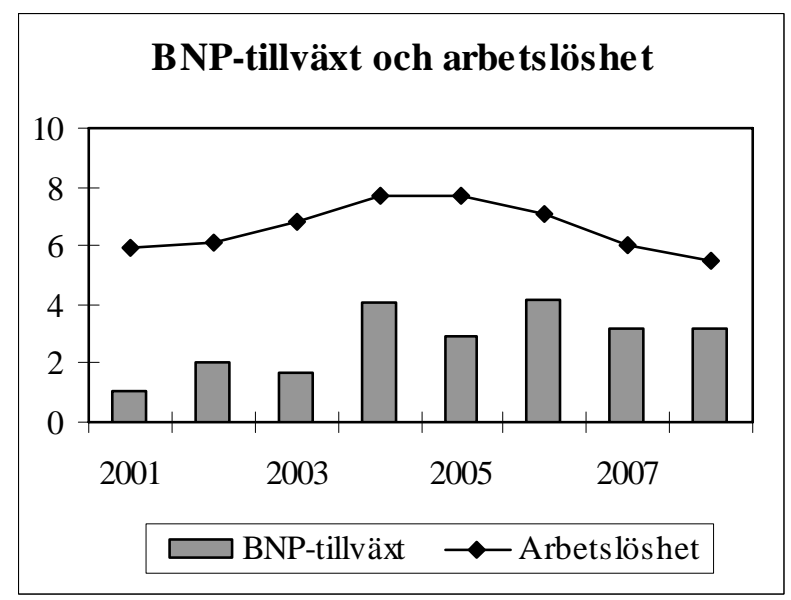

Figur 6.3 BNP-tillväxt och arbetslösheten, \% förändring.

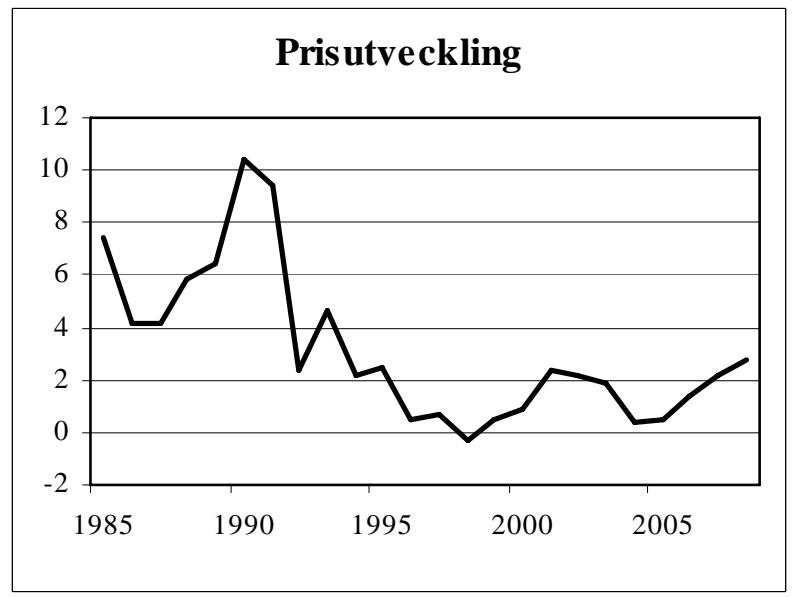

Figur 6.4 Konsumentprisindex. 


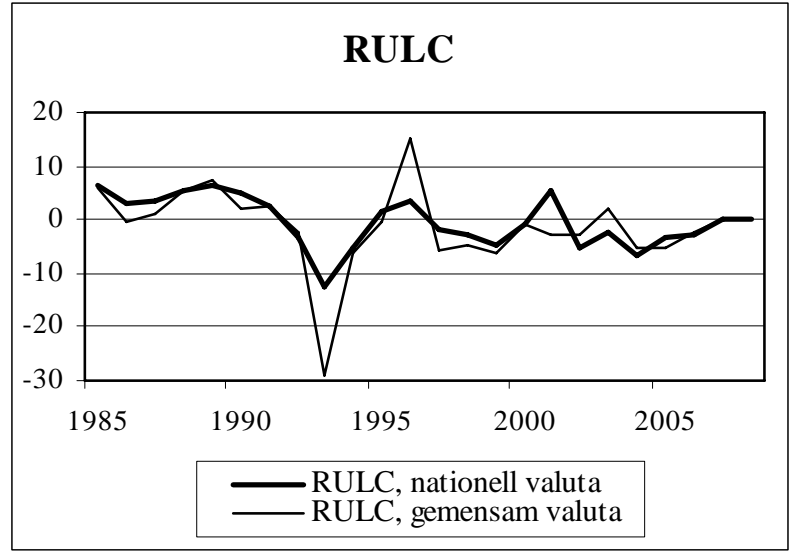

Figur 6.5 Relativ lönekostnad per producerad enhet.

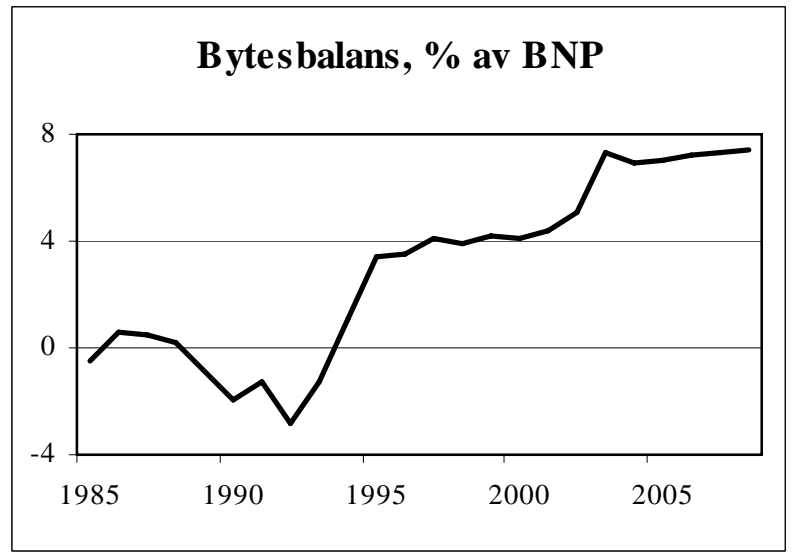

Figur 6.6 Bytesbalans, procent av BNP.

Källa: Finansdepartementet. 